\title{
Demonstrated transfer of cyanobacteria and cyanotoxins along a freshwater-marine continuum in France
}

Bormans Myriam ${ }^{1,{ }^{*}}$, Amzil Zouher ${ }^{2}$, Mineaud Emilien ${ }^{1}$, Brient Luc ${ }^{1}$, Savar Veronique ${ }^{2}$, Robert Elise ${ }^{2}$, Lance Emilie ${ }^{3,4}$

1 Univ Rennes, CNRS, ECOBIO - UMR 6553, F-35000 Rennes, France

2 IFREMER/Phycotoxins Laboratory (PHYC), F44311 Nantes, France

3 UMR-I 02 SEBIO, Campus du Moulin de la Housse, BP 1039, 51687 REIMS Cedex 2, France

4 UMR 7245 MNHN/CNRS Molécules de Communication et Adaptation des Microorganismes, 12 rue Buffon, F-75231, Paris, France

* Corresponding author : Myriam Bormans, email address : myriam.bormans@univ-rennes1.fr

\begin{abstract}
:
The frequency of cyanobacterial proliferations in fresh waters is increasing worldwide and the presence of associated cyanotoxins represent a threat for ecosystems and human health. While the occurrence of microcystin (MC), the most widespread cyanotoxin, is well documented in freshwaters, only few studies have examined its occurrence in estuarine waters. In this study we evaluated the transfer of cyanobacteria and cyanotoxins along a river continuum from a freshwater reservoir through an interconnecting estuary to the coastal area in Brittany, France. We sampled regularly over 2 years at 5 stations along the river continuum and analysed for phytoplankton and cyanotoxins, together with physico-chemical parameters. Results show that cyanobacteria dominated the phytoplanktonic community with high densities (up to $2 \times 106$ cells $\mathrm{mL}-1$ ) at the freshwater sites during the summer and autumn periods of both years, with a cell transfer to estuarine (up to 105 cells $\mathrm{mL}-1)$ and marine $(2 \times 103$ cells $\mathrm{mL}-1)$ sites. While the temporal variation in cyanobacterial densities was mainly associated with temperature, spatial variation was due to salinity while nutrients were non-limiting for cyanobacterial growth. Cyanobacterial biomass was dominated by several species of Microcystis that survived intermediate salinities. Intracellular MCs were detected in all the freshwater samples with concentrations up to $60 \mu \mathrm{g} \mathrm{L-1}$, and more intermittently with concentrations up to $1.15 \mu \mathrm{g} \mathrm{L}-1$, at the most upstream estuarine site. Intracellular MC was only sporadically detected and in low concentration at the most downstream estuarine site and at the marine outlet (respectively $<0.14 \mu \mathrm{g} \mathrm{L}-1$ and $<0.03 \mu \mathrm{g} \mathrm{L}-1$ ). Different MC variants were detected with dominance of MC-LR, RR and YR and that dominance was conserved along the salinity gradient. Extracellular MC contribution to total MC was higher at the downstream sites in accordance with the lysing of the cells at elevated salinities. No nodularin (NOD) was detected in the particulate samples or in the filtrates.
\end{abstract}




\section{Highlights}

- This study reports on the transfer of both cyanobacteria and cyanotoxins from a freshwater reservoir to the marine outlet in France. The very high correlation between the biomass of potentially toxic species and total $\mathrm{MC}$ concentrations strongly suggests that the majority of the cyanobacterial present in the estuary were toxic. Microcystis which dominated the blooms in the freshwater reservoir was the most likely genus responsible for the measured MC concentrations in the estuary, followed by $P$. agardhii both being relatively resistant to the salinity gradient. The extracellular contribution to the total MCs increased from upstream to downstream in accordance with cells lysis at elevated salinity. Both intracellular and extracellular MC variants did not show specific selection along the salinity gradient but the co-dominance of the highly toxic MC-LR and MC-YR variants is worrisome as it could impact on cyanobacterial consumers.

Keywords : Cyanobacteria, Intracellular and extracellular microcystins, Estuary, Salinity 


\section{Introduction}

47 Cyanobacterial blooms have been reported worldwide (Merel et al., 2013) and their proliferations have been increasing in recent years as a result of anthropogenic activities including eutrophication and climate warming (O'Neil et al., 2012; Rigosi et al., 2014; Paerl, 2018). This tendency is also recorded in France and in particular in Brittany (AFSSA, 2006; Pitois et al., 2014; Le Moal et al., 2019) where most of the French agricultural lands are located. Freshwater cyanobacteria produce a variety of toxins (i.e. hepatotoxins, neurotoxins, dermatotoxins) which have strong negative impacts on animal and human health (Lance et al., 2010; Metcalf and Codd, 2012; Meriluoto et al., 2017). Reports of toxic cyanobacterial blooms in Brittany have been numerous in freshwater lakes and reservoirs (Vezie et al., 1998; Brient et al., 2009; Pitois et al., 2018). Among the diversity of cyanotoxins, the hepatotoxin microcystin (MC) is largely recognised as the most common and widespread in freshwater ecosystems (Harke et al., 2016). The general structure of that cyclic heptapeptide includes a specific beta amino acid- 3-amino-9-methoxy-2,6,8-trimethyl-10-phenyl4,6-decadienoic acid - Adda (Ortiz et al., 2017; Tillett et al., 2000) as well as two amino acids that can vary leading to the identification of more than $250 \mathrm{MC}$ variants (Puddick et al., 2014). The regulation and synthesis of MC, as well as its ecological role, are complex and not yet fully understood (Neilan et al., 2013; Omidi et al., 2017). Nodularin (NOD) is also a potent cyanobacterial hepatotoxin occurring in brackish waters (Sivonen et al., 1989; Kaebernick and Neilan, 2001). It is a cyclic pentapeptide structurally similar to MC, consisting of Adda, D-glutamicacid (D-Glu), $\mathrm{N}$-methyldehydrobutyrine (MeDhb),D-erythro--methylaspartic acid (D-MeAsp) andLarginine (L-Arg) (Rinehart et al., 1988).

The transfer of cyanobacteria along the freshwater-marine continuum has been observed worldwide (Preece et al., 2017 for a review), in Africa (Ndlela et al., 2016), USA (Lehman et al., 2005; Peacock et al., 2018), South America (Dörr et al., 2010), Australia (Robson and Hamilton, 2003; Orr et al., 2004), Europe (Verspagen et al., 2006; Tonk et al., 2007; Paldavičiene et al., 2009), and Turkey (Taş et al., 2006). The majority of these studies reported on the cyanobacterial transfer being dominated by Microcystis aeruginosa demonstrating a certain salt tolerance of that species. The 

et al., 2017) and very few studies reported on MC levels high enough to affect recreational activities (Paldavičiene et al., 2009; Albay et al., 2005). In particular, MC transfer to the coastal environment resulting from freshwater discharge from an upstream reservoir has only been reported in Italy (De Pace et al., 2014) and Japan (Umehara et al., 2012). Both MC and NOD have been reported to accumulate in fish and bivalves resulting in a potential risk to humans from consumption of contaminated food (Lopes and Vasconcelos, 2011; Gibble et al., 2016; Karjalainen et al., 2007).

Here we report on the dynamics and transfer of cyanobacteria and cyanotoxins from a freshwater reservoir discharge to the marine environment during a 2 year field study, which to our knowledge is the first study in France reporting on such transfer. This study is part of a larger project aiming at the evaluation of the potential risk of contamination of aquatic organisms (i.e. bivalves) by cyanotoxins during transfer from a freshwater reservoir to an estuary mouth in Brittany, France. We present results on cyanobacterial biomass, species composition, as well as cyanotoxins concentrations of different variants of $\mathrm{MC}$ and NOD both in intracellular and extracellular forms. The quantification of those two forms of cyanotoxins are necessary as we anticipate gradual cells lysing along the salinity gradient.

\section{Materials and methods}

\subsection{Study site and sampling strategy}

In Brittany, surface water dominated rivers have short residence times (Fraisse et al, 2013) and reservoirs are generally close to marine outlets. The study site is located in the Morbihan (Brittany, France) along a continuum of moderate length $(<10 \mathrm{~km})$, from the Pen Mur freshwater reservoir upstream through the estuary and the marine outlet (Fig. 1). This study site was chosen as the Pen Mur reservoir, used for drinking water, is monitored by the Regional Health Agency (ARS) and undergoes recurrent intense cyanobacterial blooms dominated by the genus Microcystis (L. Brient, pers. comm.). Freshwater discharge from the reservoir to the estuary is frequently observed but not monitored and therefore not quantified.

\footnotetext{
111 From May 2016 to April 2018, we sampled at 5 stations along the freshwater-marine 112 gradient (F1 in the Pen Mur reservoir and F2 in the river downstream of the reservoir
} 
113 are both in the freshwater section, E1 and E2 are located in the estuarine section and

114 the site $M$ is located at the marine outlet). For each campaign, all 5 stations were

115 sampled on the same day. We consistently sampled the 3 downstream stations

116 within 1 hour of low tide to maximize the freshwater discharge and minimize the tidal

117 contribution. At each station, forthnightly to monthly water sampling was carried out

118 in the water column to: i) describe phytoplankton and cyanobacterial species

119 (identification and enumeration), and (ii) quantify cyanotoxins (MC and NOD) in the

120 cells and in the water. Physico-chemical parameters (temperature, conductivity,

121 dissolved oxygen, phosphorus and nitrogen concentrations) using a YSI 6920 multi-

122 parameter probe (YSI Environmental, Anhydre) and chemical analyses were also

123 determined at a subset of the sampling dates.

124

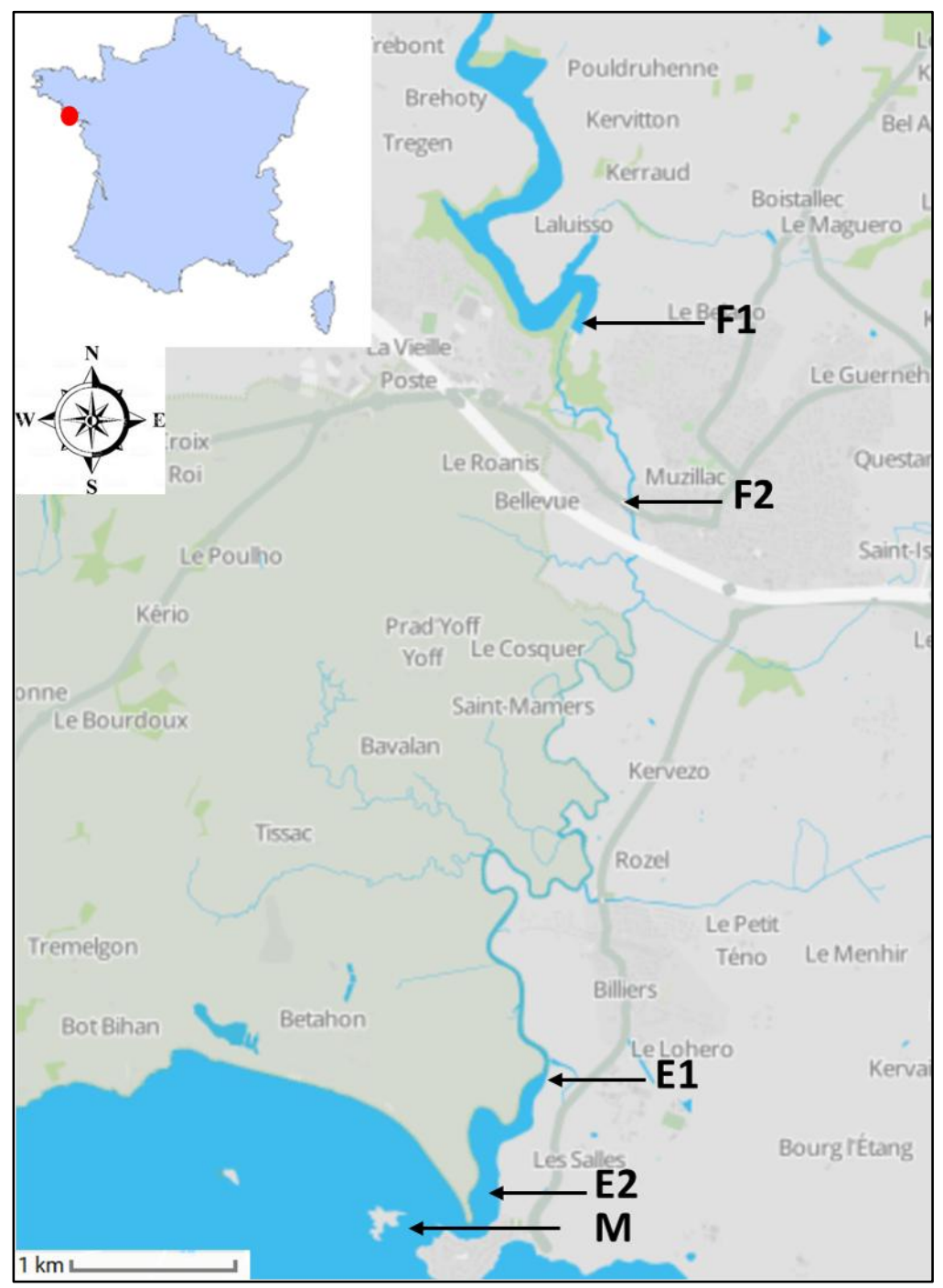

126 Fig. 1: Map of the study site and sampling stations: F1 and F2 are located in the 127 freshwater section, E1 and E2 in the estuarine section and $M$ at the marine outlet. 


\subsection{Samples analyses}

130 Samples were filtered upon arrival at the laboratory within a few hours of sampling.

131 Dissolved nutrient concentrations were measured from filtered (GF/F) water using 132 common colorimetric methods (Aminot and Chaussepied, 1983) with a Bran and 133 Luebbe Autoanalyser 3 (Axflow, Norderstedt, Germany). Nitrate was measured after 134 reduction to nitrite on a cadmium-copper column (Henriksen and Selmer-Olsen, 135 1970). Phosphate was measured following the method of Murphy and Riley (1962).

136 Phytoplankton and cyanobacteria identification and counts were conducted on fresh samples under an optical microscope (100x magnification) using a Nageotte chamber within 24 hours of sampling.

\subsection{Chemical analysis of cyanotoxins by LC-MS / MS}

141 Water samples containing cyanobacteria were filtered upon arrival at the laboratory 142 through a $0.45 \mu \mathrm{m}$ cellulose filter to separate the cell pellet for the intracellular 143 cyanotoxin analysis and the filtrate for dissolved extracellular toxins and frozen at $14420^{\circ} \mathrm{C}$ until chemical analysis. The filtrate was purified on a $\mathrm{C}_{18}$ SPE cartridge (Solid Phase Extraction) according to the ISO 20179 standard method (Anon 2005). The fraction containing the toxins was frozen until LC-MS/MS analysis. The cell pellet was ground with $250 \mathrm{mg}$ of glass beads $(0.15-0.25 \mathrm{~mm})$ and $1 \mathrm{ml}$ of $\mathrm{MeOH}$ so that cells released their toxins. Both fractions (intracellular and extracellular) were filtered by a $0.2 \mu \mathrm{m}$ filter and analyzed by Ultra Fast Liquid Chromatography (Shimadzu, Marne La Vallee, France) coupled to 5500 QTrap tandem mass spectrometry (ABSciex,

151 Villebon sur Yvette, France). Toxins were separated on a Kinetex XB C18 column $152(100 \times 2.1 \mathrm{~mm}, 2.6 \mu \mathrm{m}$, Phenomenex), with water $(\mathrm{A})$ and acetonitrile $(\mathrm{B})$, both containing $0.1 \%$ formic acid at $0.3 \mathrm{~mL} \mathrm{~min}^{-1}$ flow rate. The gradient was raised from 30 to $80 \%$ B in 5 min and was held during 1 min before dropping down during 0.5 min

155 to the initial conditions.

Mass spectrometry detection was carried out in multiple reactions monitoring (MRM) mode (positive ions). The electrospray ionization interface (ESI) was operated in positive mode using source setting: curtain gas set at 30 psi, ion spray at $5000 \mathrm{~V}$, a turbogas temperature of $300^{\circ} \mathrm{C}$, gas 1 and 2 set at 30 and 40 psi respectively and an entrance potential of $10 \mathrm{~V}$. Each toxin was identified and quantified with two 
162 transitions (Table S1): The toxin concentrations of all 10 lipophilic cyanotoxins were

163 determined using certified standards provided by CNRC (Halifax, NS, Canada). The 164 method was developed and validated internally in the IFREMER Phycotoxins 165 laboratory.

166

167

Table S1 : LC-MS/MS transitions for the 9 MC variants and NOD tested with

171 standards

\begin{tabular}{|c|c|c|c|}
\hline Toxin & Precursor ion $(\mathrm{m} / \mathrm{z})$ & $\begin{array}{c}\text { Transition }(\mathrm{m} / \mathrm{z})- \\
\text { Quantification }\end{array}$ & $\begin{array}{c}\text { Transition }(\mathrm{m} / \mathrm{z})- \\
\text { identification }\end{array}$ \\
\hline MC-LR & 995.6 & 213.2 & 374.5 \\
\hline MC-LW & 1025.6 & 375.2 & 135.2 \\
\hline MC-LF & 986.6 & 375.2 & 135.2 \\
\hline MC-LY & 1002.6 & 375.2 & 135.2 \\
\hline dmMC-LR & 981.4 & 103.0 & 135.2 \\
\hline MC-RR & 520.1 & 135.2 & 213.2 \\
\hline dmMC-RR & 512.8 & 135.0 & 103.0 \\
\hline MC-LA & 910.7 & 375.2 & 135.2 \\
\hline MC-YR & 1045.6 & 213.2 & 375.2 \\
\hline NOD & 825.5 & 227.0 & 163.2 \\
\hline
\end{tabular}

\subsection{Statistical analyses}

175 All statistical analyses were carried out using $\mathrm{R}$ studio software (R Development

176 Core Team, 2011). A Kruskal-Wallis analysis was used to test the temporal and spatial effects on physico-chemical conditions and dissolved nutrient concentrations.

178 The significance threshold was set at $p<0.05$. A Spearman correlation was applied 179 between cyanobacterial biomass and overall toxin concentrations. Changes in the 180 physico-chemical and biological conditions were characterized by a principal 181 component analyses (PCA). Analyses were performed on temperature, conductivity, 182 oxygen saturation, cyanobacterial biomass (cell $/ \mathrm{mL})$ and Shannon diversity index 183 data. 


\section{Results}

3.1. Dynamics and transfer of cyanobacteria along the freshwater marine continuum

187 Diatomophyceae and chlorophyceae occurred in winter and spring while 188 cyanobacteria dominated the phytoplankton community in Pen Mur reservoir ( $F 1$ site) 189 in summer and early fall during both years (Fig. 2). It is important to note that only 190 few sampling campaigns (6) were performed in winter and spring, while the majority 191 (18) occurred in summer and fall.

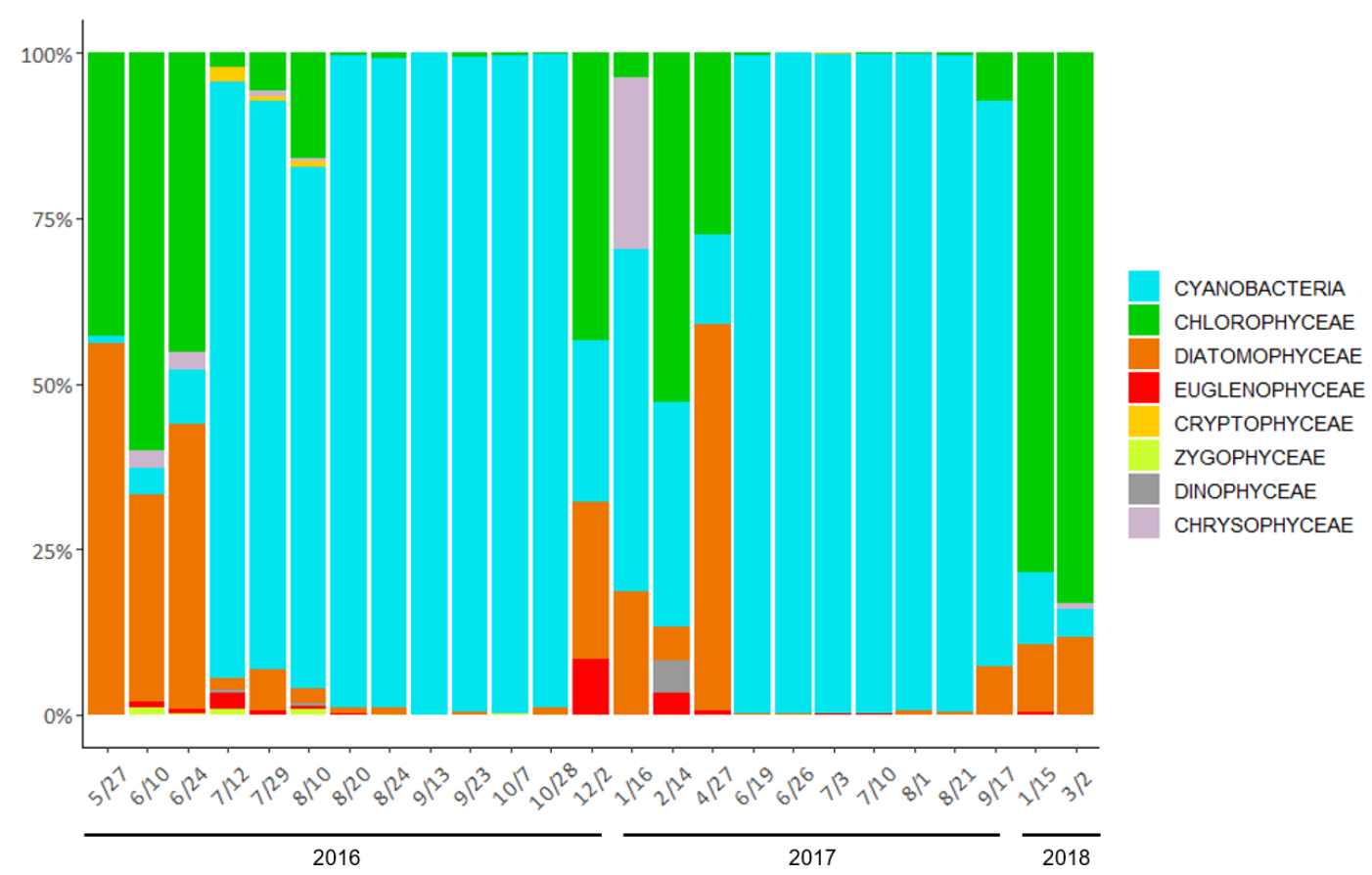

Fig. 2: Dynamics of phytoplankton community structure at the freshwater site F1 over

194 the 2 year field study. The $x$ axis corresponds to sampling dates (and not time).

196 The proliferation dynamics of cyanobacteria presented in Fig. 3 shows that the 197 biomass reached very high concentrations in the freshwater reservoir ( $F 1$ site) $\left(>10^{5}\right.$ 198 cells $\mathrm{mL}^{-1}$ ) in summer and fall (from July to October) with a peak of $10^{6}$ cells $\mathrm{mL}^{-1}$ in 1992016 and of $2 \times 10^{6}$ cells $\mathrm{mL}^{-1}$ in 2017 . These intense cyanobacterial blooms were 200 also observed at F2 in the riverine section downstream of the reservoir with a slightly 201 lower biomass. 


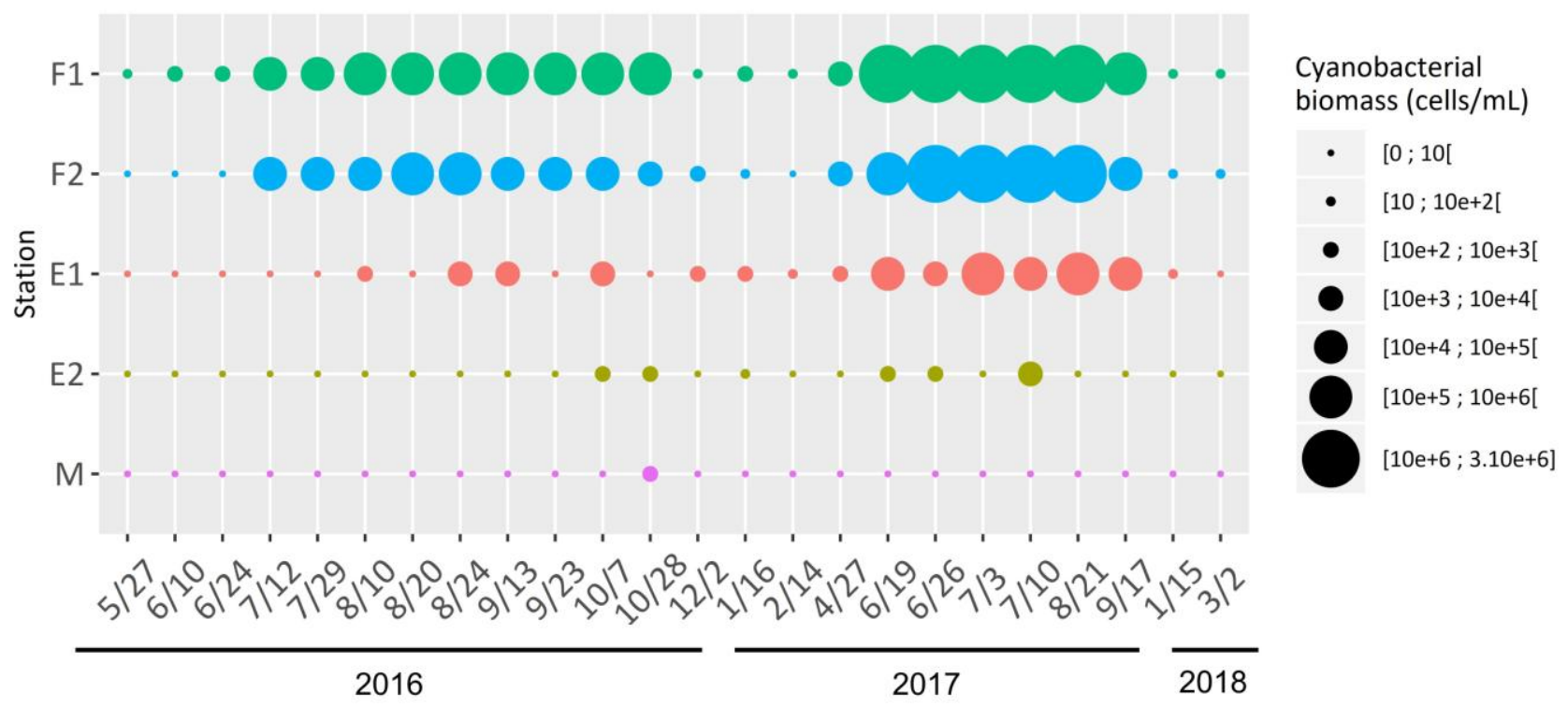

2016

203 Fig. 3: Dynamics of the cyanobacterial biomass (cells $/ \mathrm{mL}$ ) along the freshwater-marine continuum at the 5 sampling sites. The $x$ axis corresponds to sampling dates (and not time).

Transfer to the estuary was demonstrated with a progressively lower cyanobacterial

207 biomass along the estuary as the distance from the upstream reservoir increased.

208 Downstream cells concentrations were always related to upstream cells 209 concentrations suggesting that they were due to horizontal transfer and not to in situ 210 growth. A maximum of $2 \times 10^{5}$ cells $\mathrm{mL}^{-1}$ was recorded at E1 in June 2017 and a 211 maximum of $1.2 \times 10^{3}$ cells $\mathrm{mL}^{-1}$ was observed at $\mathrm{E} 2$ on the same day. At the most 212 downstream station M, coinciding with the marine outlet, a maximum of $240 \mathrm{cells} / \mathrm{mL}$ 213 was recorded (in October 2016).

\subsection{Environmental factors associated with the cyanobacterial biomass}

216 The spatial and temporal variations of cyanobacterial biomass were associated with 217 physico-chemical conditions presented in Fig. 4: a statistically significant seasonal 218 variation in water temperature was observed with maxima in June/August and 219 minima in December/February $\left(p=10^{-8}\right)$ but relatively little spatial variation along the 220 estuary $(p=0.97)$. On the contrary, conductivity exhibited a strong statistically 221 significant spatial variation $\left(p=3 \times 10^{-11}\right)$ and a relatively low temporal gradient $222(p=0.82)$. Hence temporal variation in cyanobacterial biomass was essentially 223 correlated with changes in temperature whereas spatial variation was mostly derived 224 from the longitudinal gradient of salinity/conductivity. A threshold of $18^{\circ} \mathrm{C}$ 225 corresponded to a biomass higher than $10^{5}$ cells $\mathrm{mL}^{-1}$ in the reservoir upstream. The 
226 concentration variation in dissolved oxygen gave an indication of photosynthetic 227 activity, values greater than $100 \%$ saturation corresponding to photosynthetic 228 production conditions, values around $100 \%$ indicating a balance between the water 229 and the atmosphere and values below $100 \%$ indicating respiration or consumption by 230 bacteria.
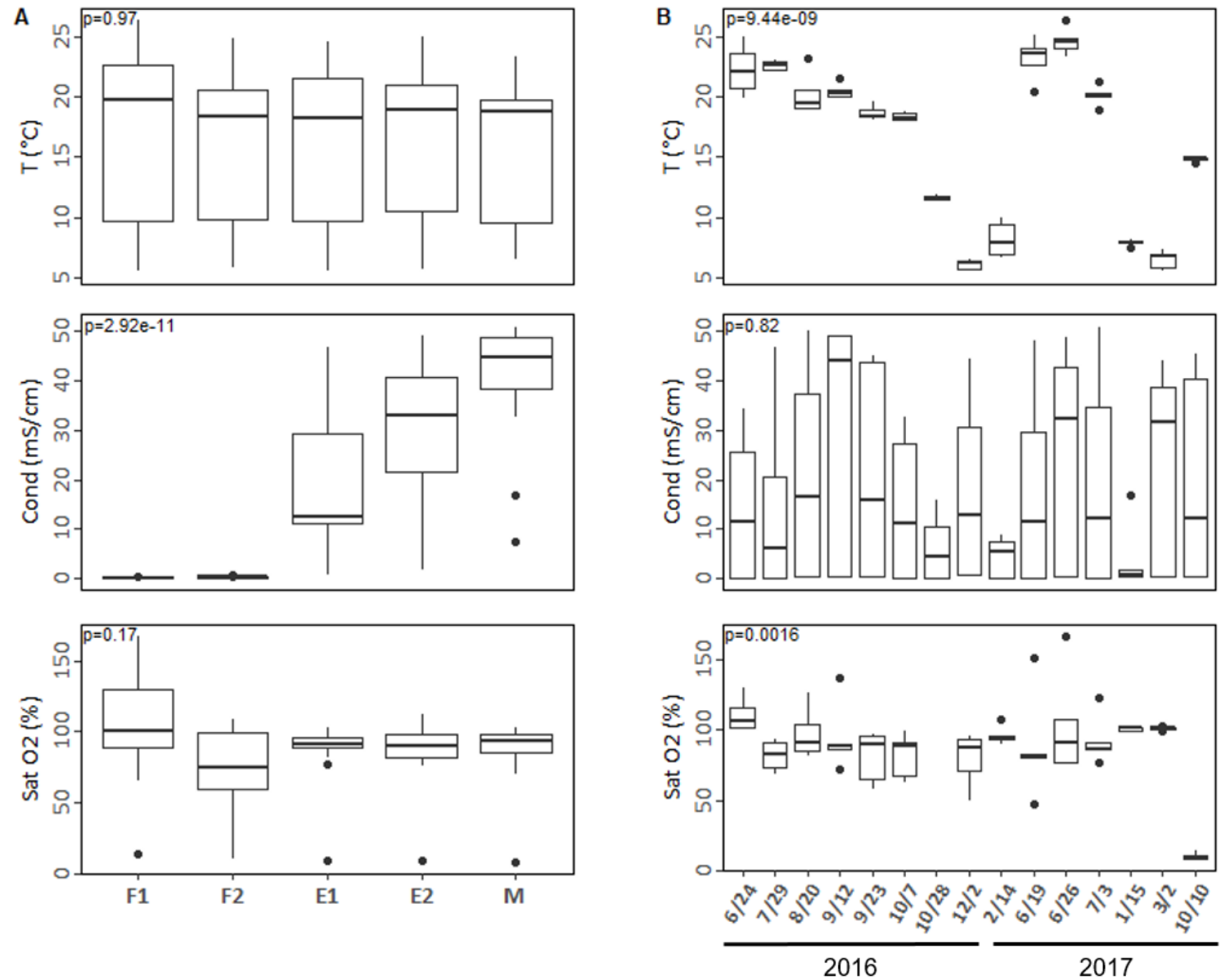

232 Fig. 4: Spatio-temporal variation of physicochemical conditions measured during the

2332 year study along the freshwater to marine continuum.

235 Dissolved oxygen displayed a statistically significant temporal variation $(\mathrm{p}=0.0016)$ 236 while no spatial variation $(\mathrm{p}=0.17)$ was observed during the study period. In the 237 reservoir ( $\mathrm{F} 1$ site) during high cyanobacterial biomass, the dissolved oxygen was 238 oversaturated, while in the shallow F2 site where low water level $(<1 \mathrm{~m})$ of near 239 stagnant waters coincided with high biological degradation and bacterial 240 consumption, the dissolved oxygen was strongly undersaturated. Further 241 downstream in the estuary (E1 and E2 sites) the dissolved oxygen was around 80 to $242100 \%$ saturation. 

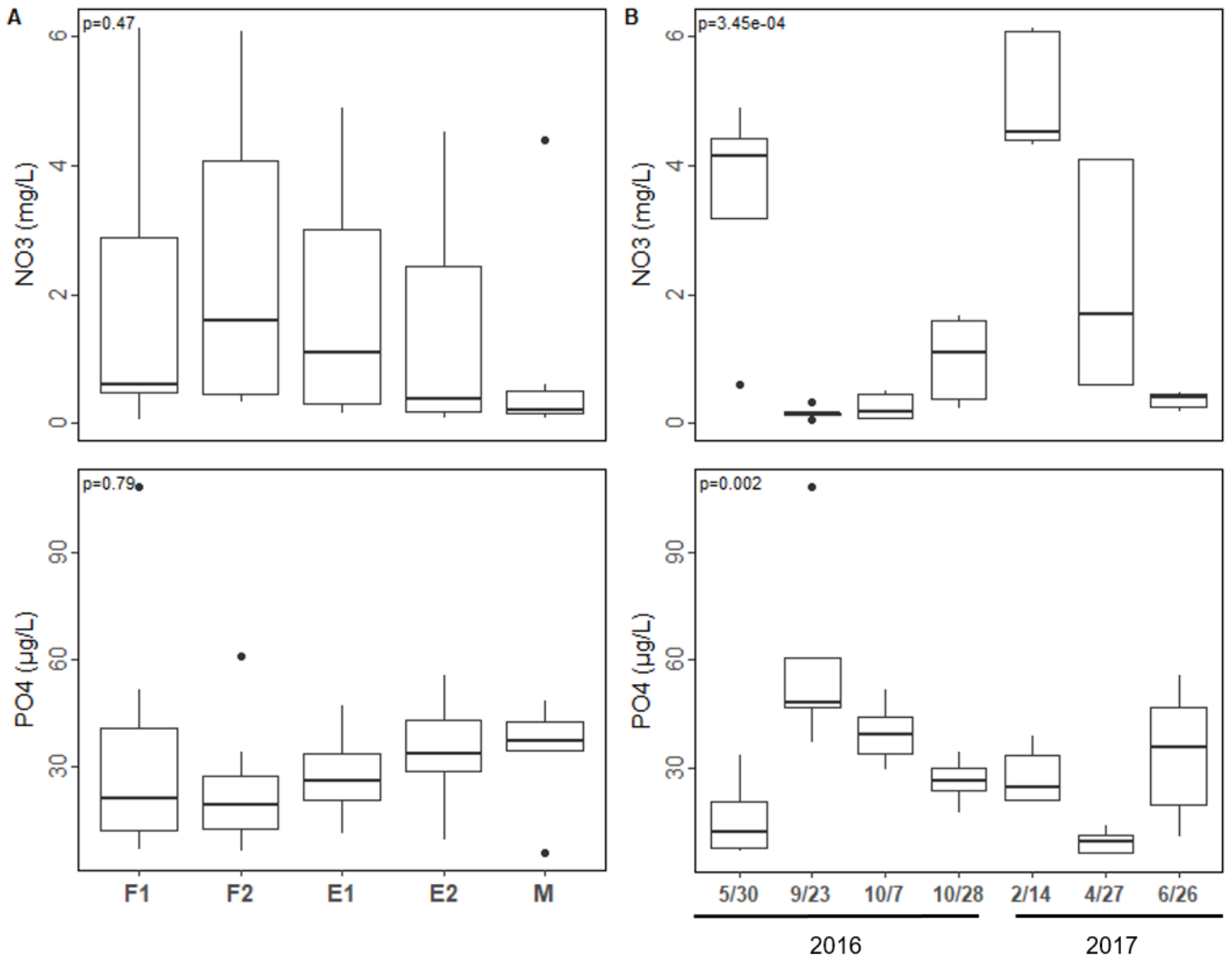

Fig. 5: Spatio-temporal variation of dissolved nutrient concentrations measured

246 during the two year study along the freshwater to marine continuum.

248 Both dissolved nutrients (NO3 and PO4) displayed a statistically significant temporal 249 variation while the spatial variation only showed tendencies (Fig. 5). Nitrate 250 concentrations presented an upstream to downstream decrease while phosphate 251 concentrations showed the opposing trend with higher values downstream.

\subsection{Cyanobacterial species composition along the salinity gradient}

254 The composition of cyanobacterial populations was very diverse in the freshwater reservoir with 27 species present during the study. As Fig. 6 shows, during the

256 strongest proliferations (from August to October both years), a dominance of the 257 genus Microcystis was observed at the F1 site with up to 7 different species of 258 Microcystis i.e. M. aeruginosa, M. viridis, M. flos aquae, M. wesenbergii, M. novacekii and Microcystis sp. This same diversity and composition was observed at the F2 site 
260 (not shown). There was a shift in the dominant Microcystis species between 2016 261 and 2017 with a mix of M. viridis, M. flos aquae, M. aeruginosa and Microcystis sp in 2622016 and an almost monospecific bloom of M. aeruginosa in 2017.

264 The transfer to the estuary selected for certain species according to their adaptation 265 to the new physicochemical conditions, mainly salinity (recorded as conductivity). Up 266 to half of the cyanobacterial species were present in the estuarine section: 14 267 species at E1, 7 at E2 and 1 at $\mathrm{M}$. The maximum conductivity recorded during 268 sampling in summer and fall was $12 \mathrm{mS} \mathrm{cm}^{-1}$ at E1, $35 \mathrm{mS} \mathrm{cm}^{-1}$ at E2 and $50 \mathrm{mS} \mathrm{cm}$

$269{ }^{1}$ at M. The species that survived the transfer through the estuary were several 270 species of Microcystis, Aphanizomenon sp., Pseudanabaena limnetica and 271 Planktothrix agardhii, all recorded at the estuarine site E2. P. agardhii was the only 272 cyanobacterial species recorded at the marine outlet $M$. The transfer of $P$. agardhii 273 was observed on 4 October 2016 between the freshwater site F2 (density P. agardhii 2747400 cells $\mathrm{mL}^{-1}$, Microcystis sp 22000 cells $\mathrm{mL}^{-1}$ ), through the estuarine E1 site 275 (density $P$. agardhii 4480 cells $\mathrm{mL}^{-1}$, Microcystis sp 2200 cells $\mathrm{mL}^{-1}$ ), and the 276 estuarine E2 site ( $P$. agardhii density 533 cells $\mathrm{mL}^{-1}$, Microcystis sp 267 cells $\mathrm{mL}^{-1}$ ). 277 Another transfer to the marine outlet was observed at the end of October 2016 278 between E2 (432 cells mL ${ }^{-1}$ of $P$. agardhii, 480 cells mL ${ }^{-1}$ of total cyanobacteria) and $279 \mathrm{M}$ (240 cells $\mathrm{mL}^{-1}$ of $P$. agardhii, $100 \%$ cyanobacteria), while $P$. agardhii was not the 280 majority at F2 (160 cells $\mathrm{mL}^{-1} P$. agardhii, 4400 cells $\mathrm{mL}^{-1}$ Microcystis sp.). Among 281 the other filamentous cyanobacteria surviving the estuarine transfer, Pseudanabaena 282 limnetica was observed on 26 June 2017 with a decreasing concentration from 283165120 cells $/ \mathrm{mL}$ at $\mathrm{F} 1$ to 7680 cells $\mathrm{mL}^{-1}$ at $\mathrm{E} 1$ down to 192 cells $\mathrm{mL}^{-1}$ at $\mathrm{E} 2$ while 284 Aphanizomenon sp was observed on 27 April 2017 from 220 cells $\mathrm{mL}^{-1}$ at $\mathrm{F} 2$, down 285 to 132 cells $\mathrm{mL}^{-1}$ at $\mathrm{E} 1$ and 8 cells $\mathrm{mL}^{-1}$ at E2. It is interesting to note that the relative 286 transfer of filamentous cyanobacteria was higher than that of either unicellular 287 (Aphanocapsa) or colonial (Microcystis). Of the transferred Microcystis species, $M$. 288 viridis was observed further downstream than $M$. aeruginosa and M. flos aquae in 2892016 while the opposite was observed in 2017, in accordance with the relative 290 biomass in the freshwater section. 

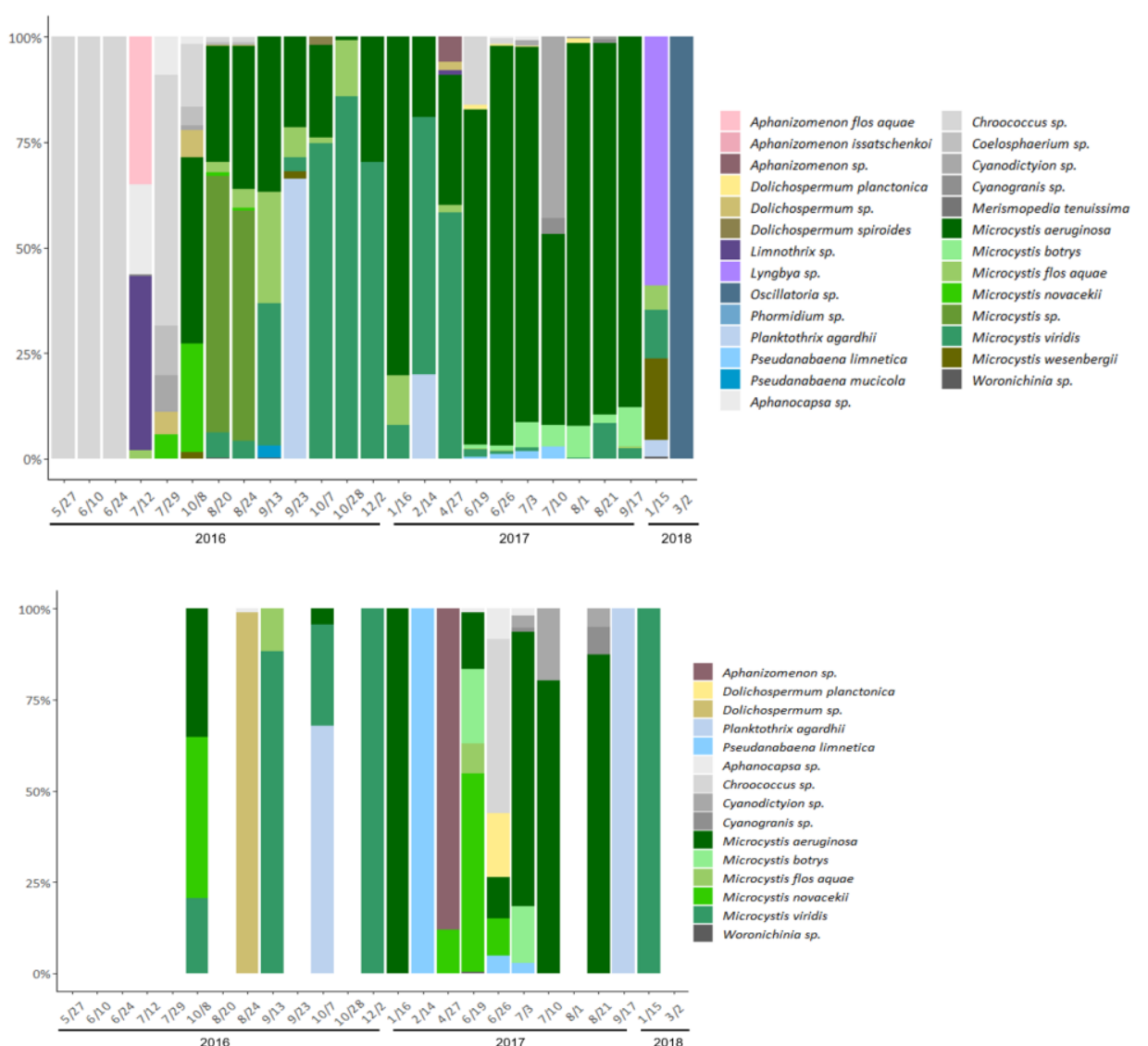

292
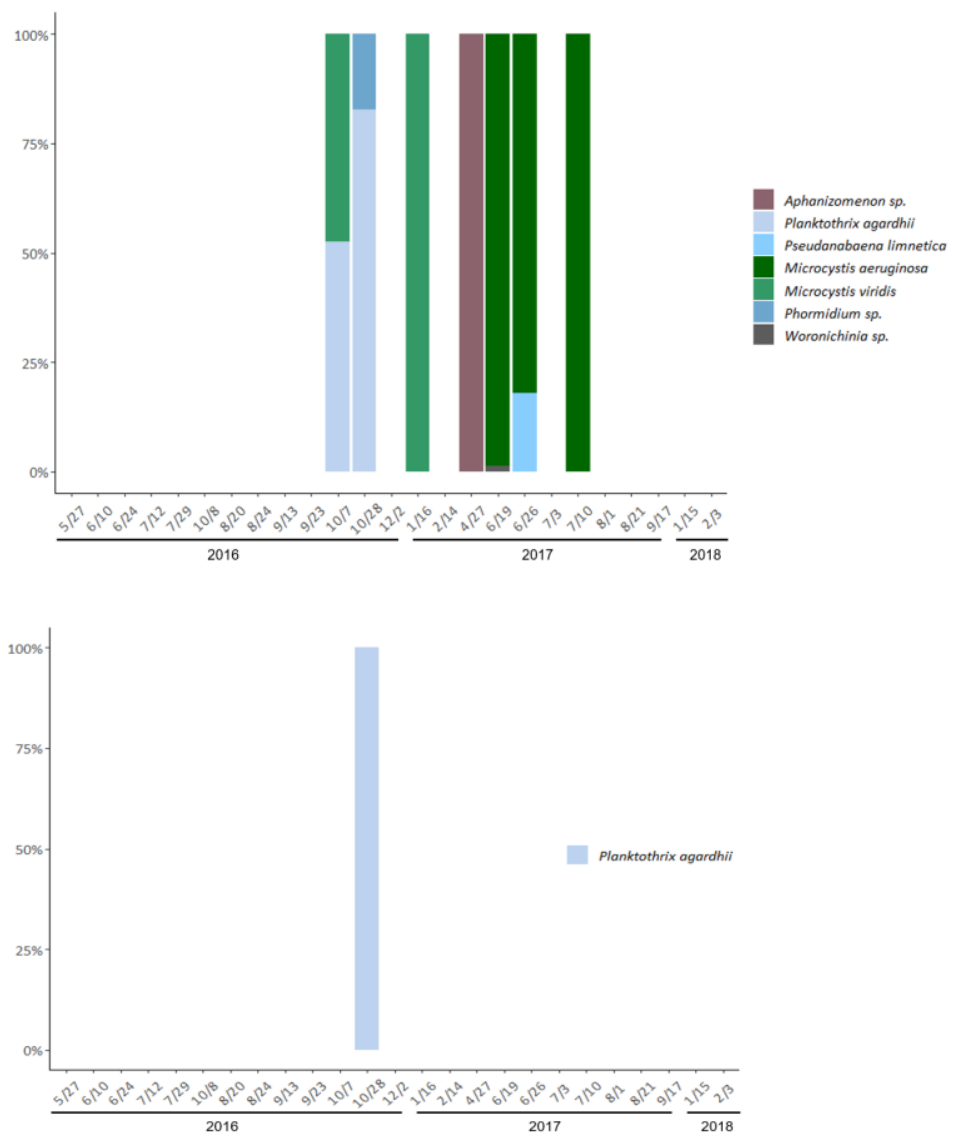

296 Fig. 6: Dynamics of cyanobacterial species composition at stations F1, E1, E2 and M 297 over the 2 year field study period. 
299 The cyanobacterial species diversity was also quantified through the cyanobacterial 300 Shannon index which is presented in Fig. S1. A gradual decrease of the Shannon 301 index along the salinity gradient is observed together with higher values in summer 302 and fall.
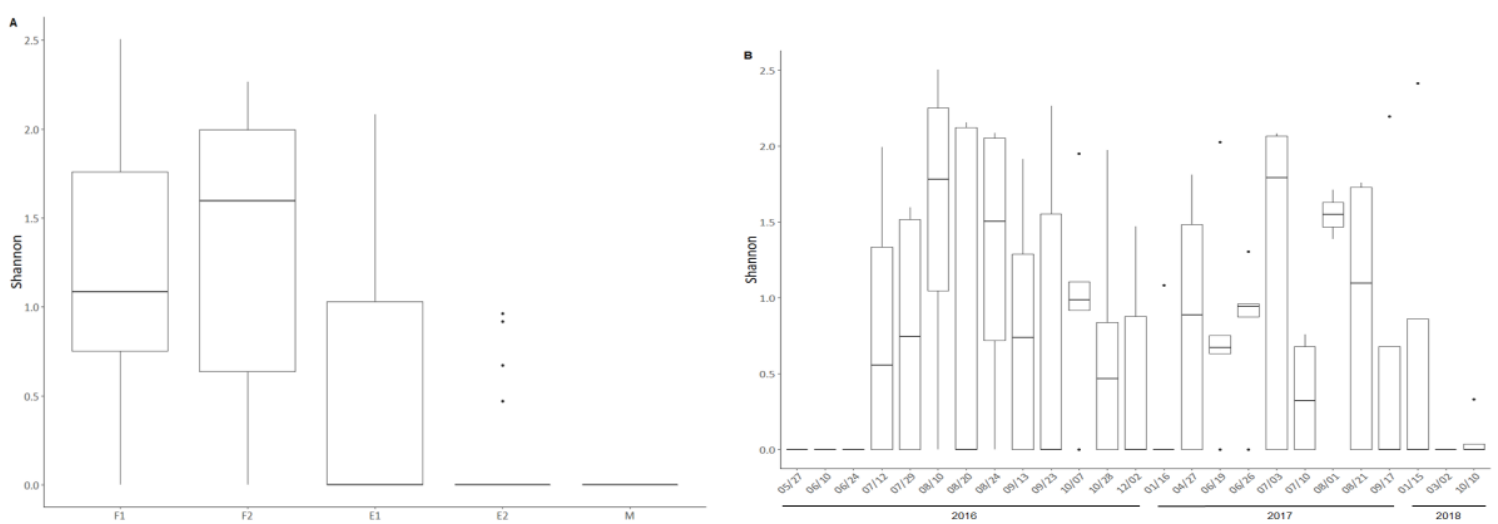

Fig. S1: Spatial and temporal variation of the cyanobacterial Shannon diversity index

A PCA analysis performed on the complete dataset (Fig. S2) confirmed the stronger role of salinity (i.e. conductivity) in structuring the spatial distribution of the observations together with the Shannon diversity index, while the cyanobacterial biomass was most strongly associated with elevated temperature and dissolved oxygen concentration.

(Axes F1 and F2: 63.91\%)

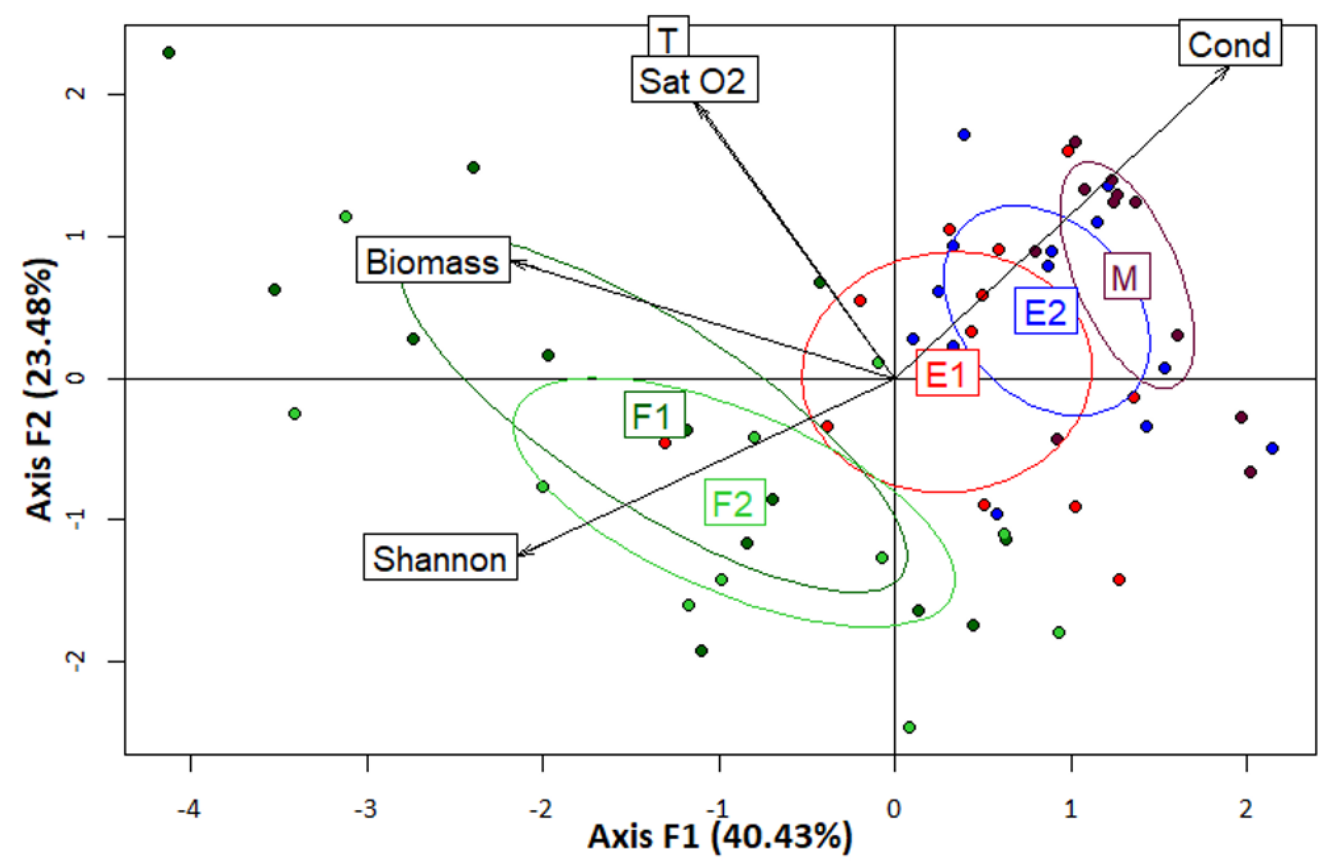


313 Fig. S2: PCA analysis highlighting the spatial variation in physico-chemical ( $T, O 2$,

314 Cond) and biological parameters (cyanobacterial biomass, Shannon index)

316 3.4 Transfer of cyanotoxins along the freshwater-marine continuum

317 This study presents the concentrations of non-protein bound lipophilic cyanotoxins,

$318 \mathrm{MC}$ and NOD in particulate samples and in the filtrates during the field campaigns of

3192016 and 2017. In particular, the intracellular and extracellular forms of MC are

320 separated to consider the potential risk associated with the lysing of the cells at high

321 salinities.

322

\subsubsection{Intracellular toxins}

324 Firstly, the toxins analysis of the particulate samples of the different stations didn't reveal the presence of NOD, which corroborates the observation of cyanobacteria species not potentially producing NOD. The time variation shows the annual reproducibility with measured concentrations and transfer of MC occurring in both 2016 and 2017 with higher toxin concentrations reached in 2017 (Fig. 7).

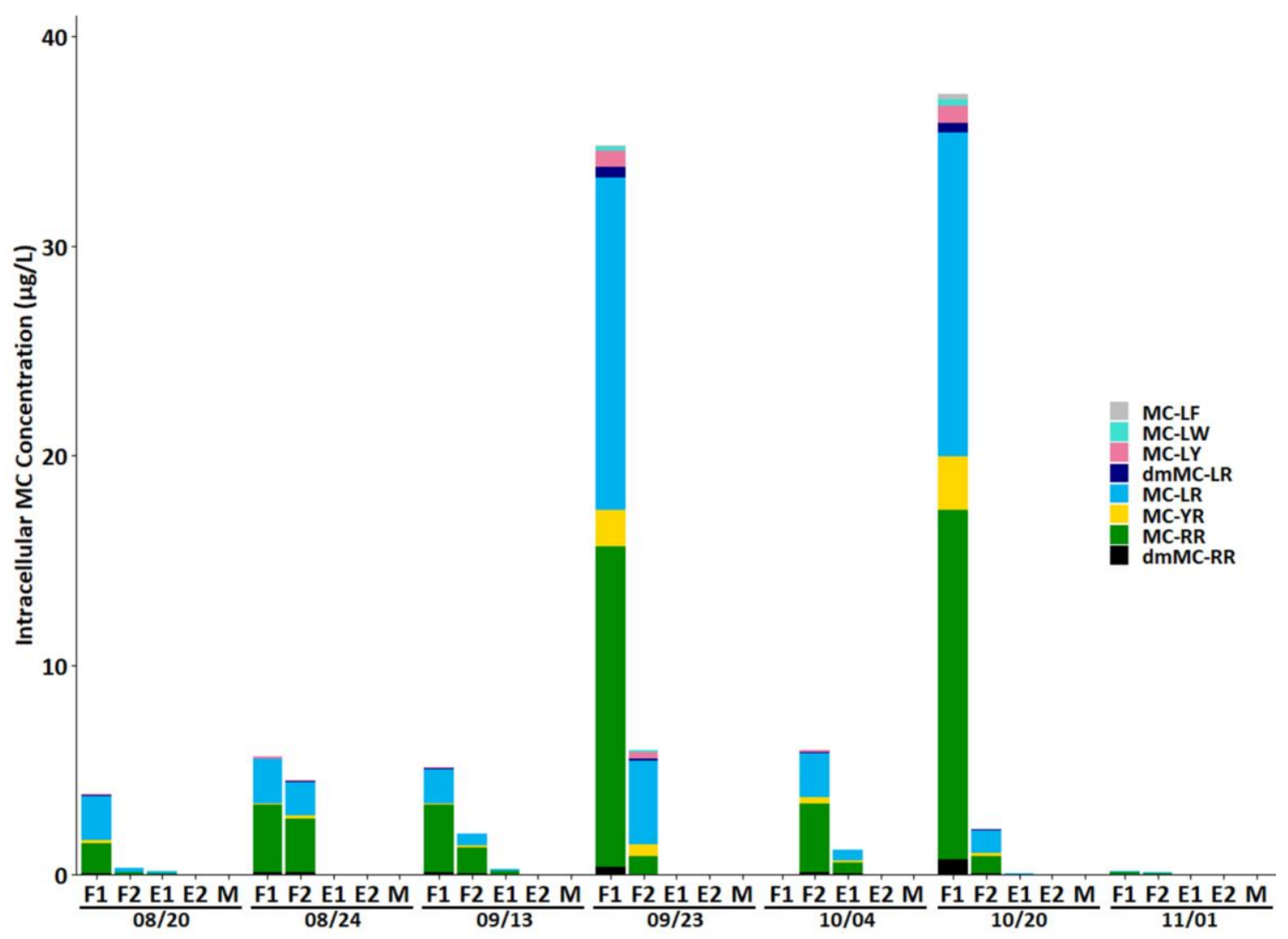




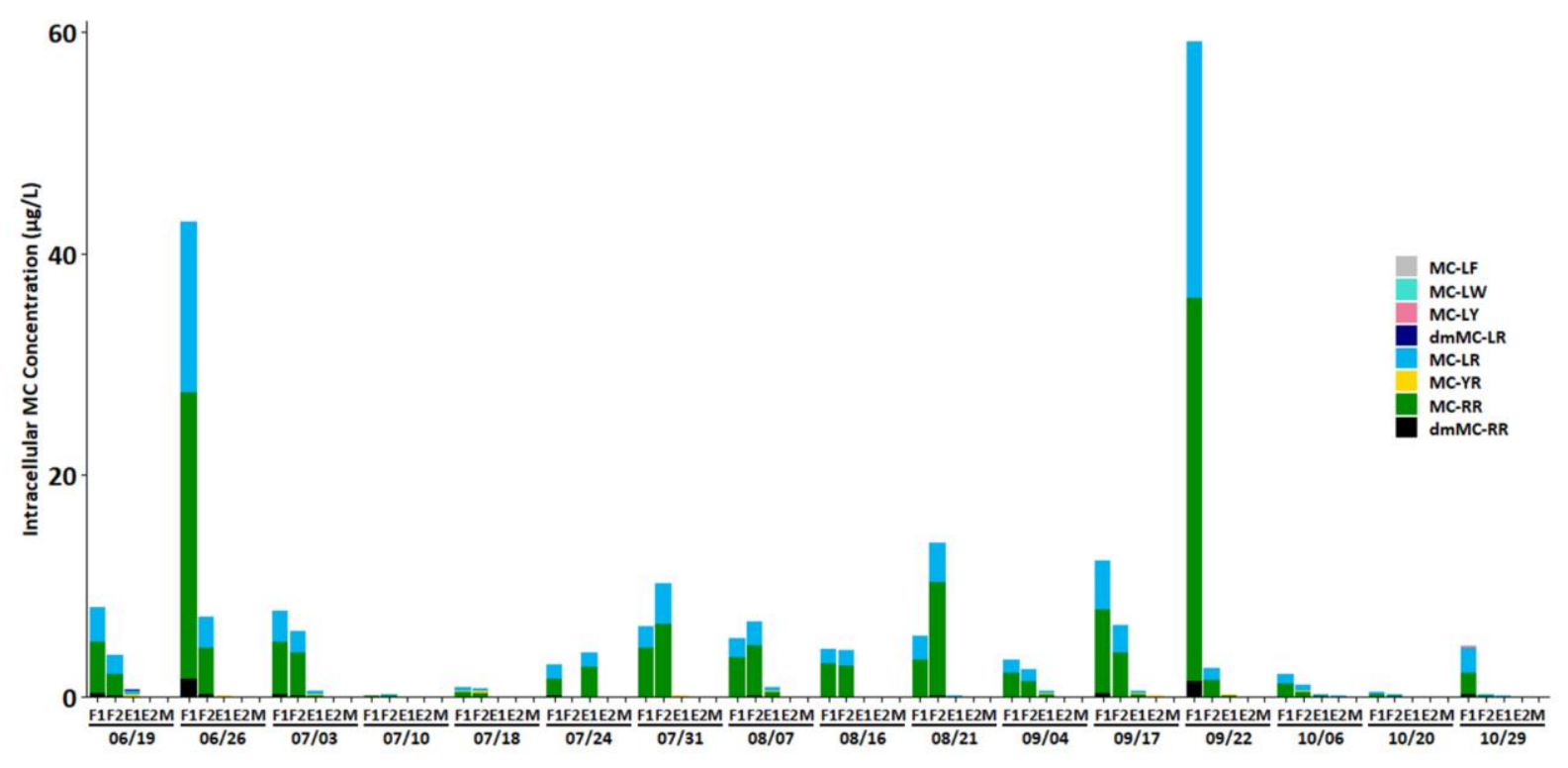

332 Fig. 7: Intracellular concentrations of $M C$ variants in the cyanobacteria during the 333 field campaigns of A) 2016 and B) 2017. Note that the $x$ axis corresponds to 334 sampling dates (and not time).

336 While the presence of MC was recorded in all the freshwater samples (at F1 and F2), 337 a high temporal variation in concentration was observed with a maximum 338 concentration of total MC (sum of the MC analogs) of $40 \mathrm{\mu g} \mathrm{L}^{-1}$ in September / 339 October 2016 and $60 \mu \mathrm{g} \mathrm{L}^{-1}$ in September 2017. Among the MC variants observed, 340 some MC analogs (MC-RR, MC-LR, dmMC-RR and MC-YR) were detected in all 341 samples while others (dmMC-LR, MC-LY, MC-LW, MC- LF) were only recorded in 342 some samples. The three dominant variants at F1 were MC-LR, MC-RR and MC-YR. 343 The total MC values at F2 reached a maximum of $14 \mu \mathrm{g} \mathrm{L}^{-1}$ with a dominance of $\mathrm{MC}$ 344 RR, MC-LR, dmMC-RR and MC-YR. A demonstrated transfer of cyanotoxins through 345 the estuary was recorded on many occasions (Table 1) with progressively lower 346 intracellular toxins concentrations reaching $1.15 \mathrm{\mu g} \mathrm{L}^{-1}$ at $\mathrm{E} 1$ (comprising of MC-RR, 347 MC-LR, MC-YR, dmMC-RR). In a less frequent manner, a maximum of $0.14 \mu \mathrm{L} \mathrm{L}^{-1}$ 348 was recorded at E2 (comprising of MC-RR, ML-LR) and a maximum of $0.03 \mu \mathrm{g} \mathrm{L}^{-1}$ at 349 site M (MC-RR, MC-LR). In summary, we observed a gradual decrease in 350 occurrence and in concentrations of intracellular toxins from upstream to 351 downstream. 


\begin{tabular}{|c|c|c|c|}
\hline Sites & \multicolumn{2}{|c|}{ FO \% intra MC (Jun - Nov) } & Max intra MC $\boldsymbol{\mu g} / \mathbf{L}$ \\
\hline F1 & $\mathbf{2 0 1 6}$ & $\mathbf{2 0 1 7}$ & \\
\hline F2 & 100 & 100 & 60 \\
\hline E1 & 100 & 100 & 14 \\
\hline E2 & 67 & 87 & 1.15 \\
\hline M & 17 & 38 & 0.14 \\
\hline
\end{tabular}

Table 1: Frequency of occurrence (in \%) and maximum concentrations of intracellular $M C$ at the 5 stations during the period June to November of both sampling years

The results of this study show relatively strong overall correlation between the amount of toxins in the phytoplankton samples and the total cells density of potentially toxic cyanobacteria (correlation coefficient of $0.85, p=10^{-11}$ ). However, when we consider relationships on specific dates, the correlation varies with the dominant cyanobacterial species. For example, in August 2016, a maximum of $5 \mu \mathrm{g}$ $M C L^{-1}$ was observed at site $F 1$, associated with a cyanobacterial density of 900,000 cells/mL composed mainly of Microcystis sp, whereas up to $40 \mu \mathrm{g} \mathrm{MC} \mathrm{L}^{-1}$ were measured at the same site in October 2016, associated with a density of 360,000 cells $\mathrm{mL}^{-1}$ composed essentially of the species $P$. agardhii. Transfer of $P$. agardhii (4480 cells $\mathrm{mL}^{-1}$ ) to the estuarine site E1 in early October 2016 coincided with the

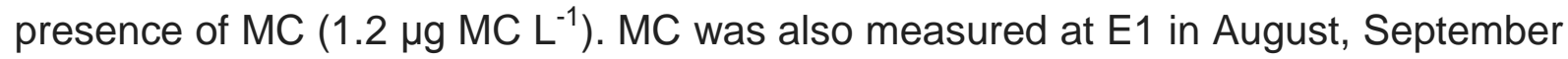

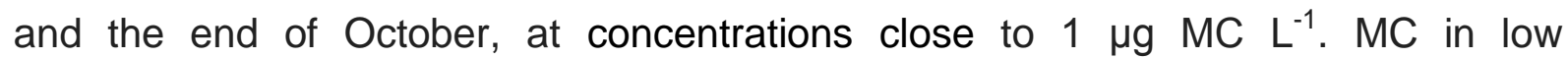
concentration was measured in the particulate samples at E2 and at M despite the presence of low density cyanobacteria.

\subsubsection{Extracellular toxins}

The extracellular toxins (measured in the filtered water) were analyzed only from July 2017 to October 2017 (Fig. 8). Similarly to the intracellular fraction, no NOD was detected. The extracellular MC profiles revealed a dominance of MC-LR, MC- RR and MC-YR. Maximum MC concentrations of $0.65 \mu \mathrm{g} \mathrm{L}^{-1}$ were found at $\mathrm{F} 1$ in the 
upstream freshwater reservoir. We observed higher $\mathrm{MC}$ concentrations downstream of F2 during August and September 2017 in the estuarine section and marine site.

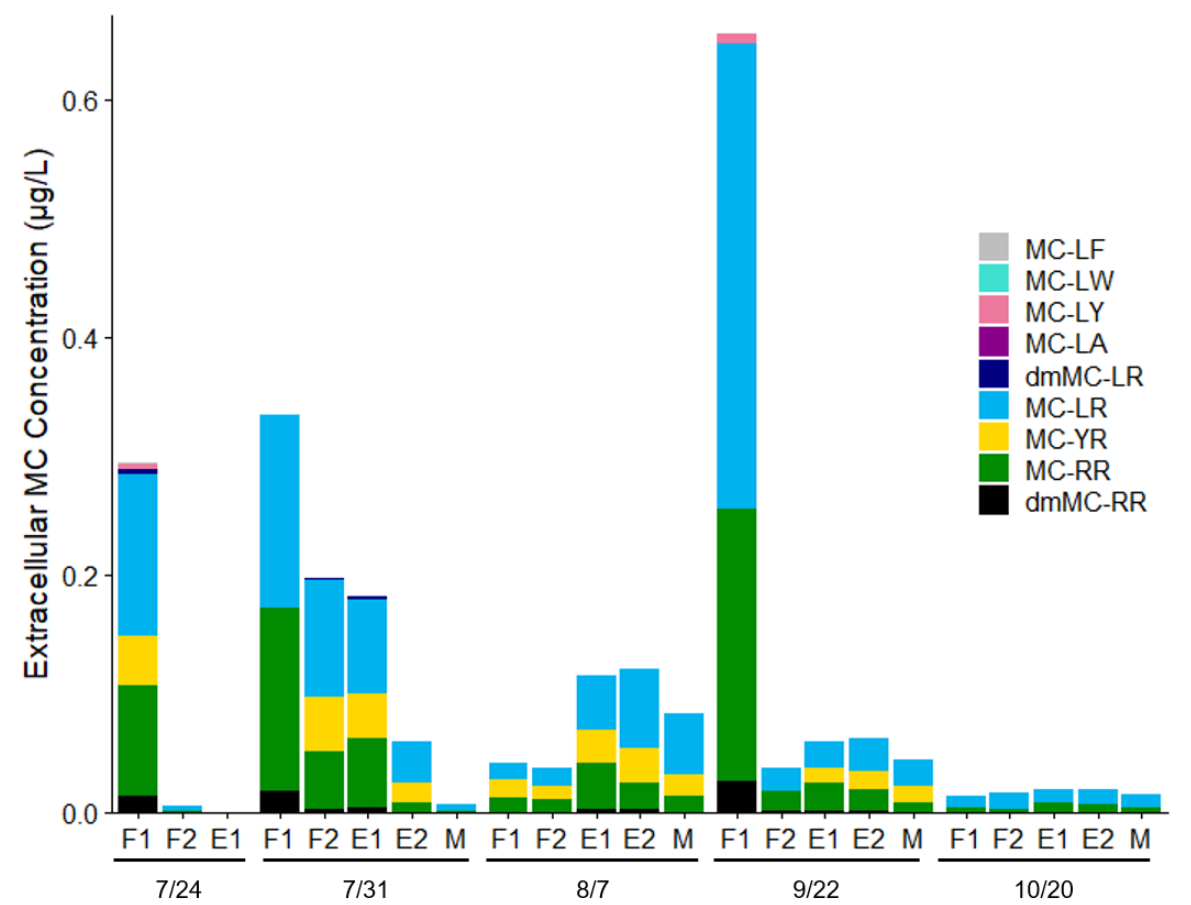

384 Fig. 8: Extracellular concentrations of $M C$ variants in the filtered water at the 5

When comparing ratios of extracellular $\mathrm{MC}$ to the total MC (intracellular + 388 extracellular fractions) along the salinity gradient, we observed a consistent trend 389 with minimal contribution of extracellular toxins in freshwater and a gradual increase 390 with increasing salinities (Fig. 9). At site E1 where the maximum conductivity 391 recorded during sampling during 2017 was $12 \mathrm{mS} \mathrm{cm}^{-1}$, the extracellular contribution 392 was up to $50 \%$, while it increased to $100 \%$ at sites $\mathrm{E} 2$ and $\mathrm{M}$ where conductivities 393 were above 35 and $47 \mathrm{mS} \mathrm{cm}^{-1}$ respectively. 


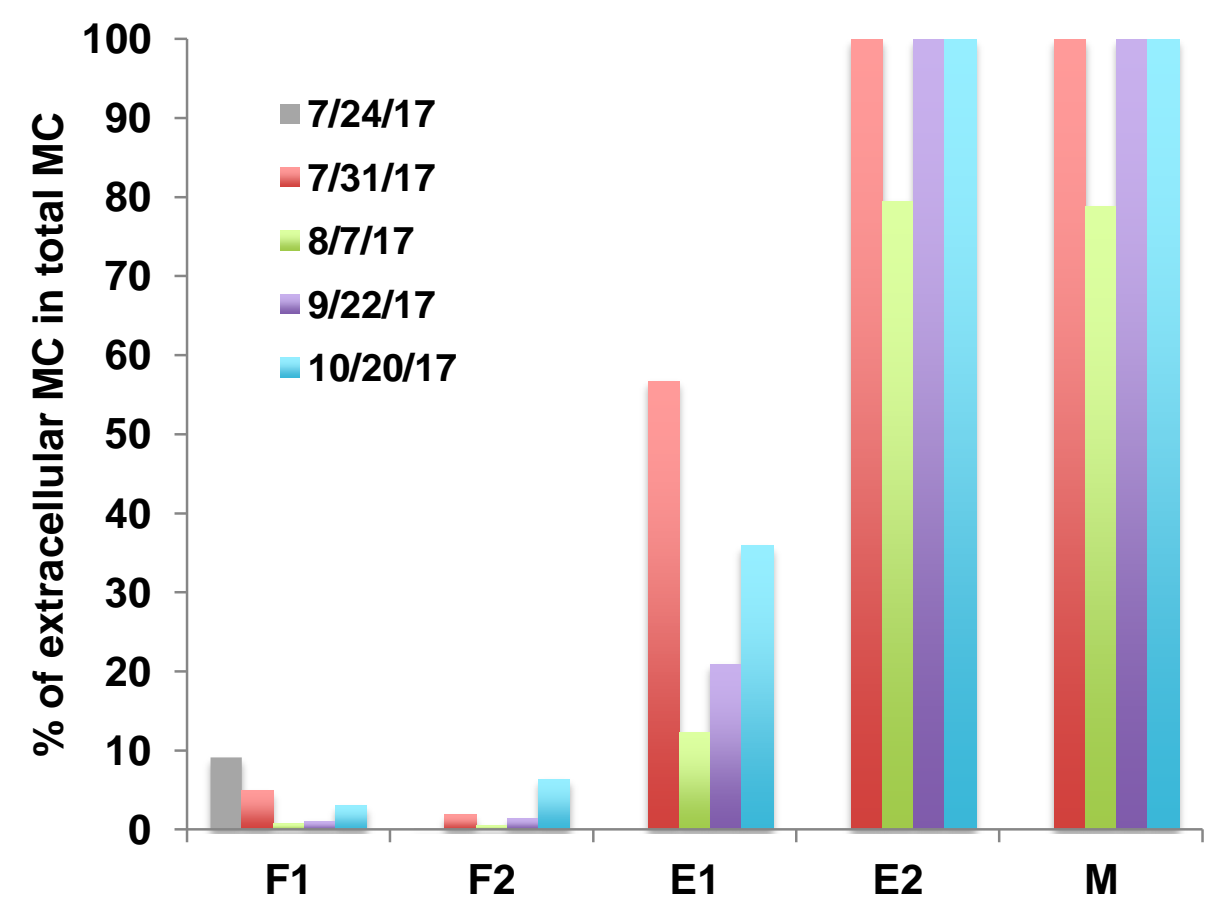

Fig. 9: Contribution of extracellular $M C$ to the total $M C$ concentrations at the 5 400 sampling sites during summer and fall 2017

\section{Discussion}

This study demonstrated over 2 successive years the recurrent transfer of 406 cyanobacteria and cyanotoxins along the freshwater - marine continuum in a Brittany 407 estuary, France. This result is in accordance with published studies worldwide. This 408 transfer was first reported in the late 1980's in Europe (Sivonen et al., 1989) and 409 USA (Paerl, 1988) but have gained an interest recently (Preece et al, 2017) and likely 410 to increase in frequency in the future (Paerl et al., 2018). Although the biomass was 411 lower than in the freshwater reservoir, cyanobacterial biomass of up to $2 \times 10^{5}$ cells $412 \mathrm{~mL}^{-1}$ was observed in the estuarine section. These cyanobacteria could therefore 413 contribute significantly to the phytoplankton community structure of the estuary, 414 which has typically a much lower biomass (usually reported in cells $\mathrm{L}^{-1}$ ) than in 415 freshwater, or serve as food source for invertebrates. While the temporal variation in 416 cyanobacterial densities was mainly associated with temperature, spatial variation 417 was due to salinity while nutrients were unlikely to limit cyanobacterial growth. Nitrate 418 presented an upstream to downstream decrease suggesting a freshwater dominant 419 source. Phosphate values showed the opposing trend with higher values 
downstream and in particular at the outlet where we expect sediment resuspension to be the largest, based on the observed high concentrations of suspended particles.

Although the freshwater discharge was not monitored and therefore not quantified, the progressive increase in salinity near the surface was a good indicator of dilution. Possible light limitation could also be important but the short residence time (of the order of one to two days), inferred from observations of the surface velocities during sampling, would not permit in situ growth. Hence we suggest that the lower biomass in the estuary results from freshwater discharge dilution with estuarine waters.

The dominant blooming genus in the upstream freshwater reservoir was overwhelmingly Microcystis, consistent with the most widespread cyanobacterial occurrence of Microcystis in freshwaters worldwide (Harke et al., 2016) and as well as in Brittany (Pitois et al., 2014). While cyanobacterial transfer from freshwaters to estuaries has been reported for around 20 years, the majority of studies worldwide reported that $M$. aeruginosa was the dominant species transferred to coastal waters (Preece et al., 2017 for a review). M. aeruginosa is described as one of the freshwater cyanobacteria with the highest salinity tolerances (Verspagen et al., 2006) but variable thresholds have been observed from 4 ppt (Chen et al., 2015), 10 ppt (Lewitus et al., 2008; Tonk et al., 2007) to 35 ppt (Miller et al., 2010 ; Black et al., 2011) possibly showing strong intraspecific variability. In this study, different Microcystis species were transferred through the estuary in 2016 and 2017, in accordance with their relative biomass upstream. Therefore we cannot suggest a stronger resistance of either of the Microcystis species (M. aeruginosa, M. viridis and M. flos aquae). While the mucilage associated with the colonial form of Microcystis is likely to protect the cells from osmotic shock at high salinity, as suggested by Kruk et al.,2017 and Martínez de la Escalera et al., 2017, the relative resistance of the different Microcystis species is not known. Filamentous cyanobacteria i.e. Planktothrix and Pseudanabaena have been shown in this study to also survive the transfer through the estuary and therefore the salinity stress. The salinity tolerance of $P$. agardhii has been recently tested on brackish isolated species and a tolerance value of up to a salinity of 15 has been found (Vergalli et al., 2016). The transfer of Planktothrix agardhii through an estuary has been recently reported on one occasion although the bloom was non toxic (Churro et al., 2017). Pseudanabaena sp. has 
454 been occasionally reported in the Baltic Sea (Lopes and Vasconscelos, 2011), 455 however, the role of the mucilage/sheath around the filaments, as a potential 456 protective morphological characteristic has not been suggested. On the other hand 457 unicellular species present in relatively high numbers in the freshwater reservoir (i.e. 458 Aphanocapsa sp., Coelosphaerium sp., Cyanodiction sp. or Cyanogranis sp.) were 459 not found in the estuary. A possible explanation besides a sensitivity to salinity is that 460 these species might be difficult to identify in samples with high suspended matter, 461 and therefore not accounted for in the counting.

462

463 Intracellular MC was detected in all samples in the freshwater section with 464 concentrations reaching $40 \mathrm{\mu g} \mathrm{L}^{-1}$ in 2016 and $60 \mu \mathrm{g} \mathrm{L}^{-1}$ in 2017. These levels are 465 much higher than the alert 3 warning level of $10-20 \mathrm{\mu g} \mathrm{L}^{-1}$ of the World Health 466 Organization forbidding any recreational activities in waterbodies (Ibelings et al., 467 2014; Funari et al., 2017). In this study, the measured gradual decrease in 468 cyanobacterial biomass was accompanied by a decrease in intracellular MC 469 concentrations from upstream to downstream indicating a likely dilution effect as expected due to strong tidal influence, even though we minimized that influence by sampling within one hour of low tides. This decrease has also been reported in the 472 San Francisco Estuary (Lehman et al., 2008) and in Monterey Bay (Gibble and 473 Kudela, 2014). A concomitant physiological response to MC production could also be 474 possible at high salinity. Indeed, the effect of salinity on the physiology of $M$. aeruginosa has demonstrated a reduction in the production of MCs under salt stress (Black et al., 2011; Martín-Luna et al., 2015).

A highly significant overall relationship between potentially toxic cyanobacterial biomass and intracellular MC concentrations was found. In 2017, there was an early 480 summer dominance of the small unicellular non-toxic cyanobacteria Cyanodyction $s p$. 481 and Cyanogranis sp. which did not occur in 2016 when the summer blooms were 482 dominated by the potentially toxic $M$. viridis. The toxicity of Microcystis is also known 483 to vary among species, $M$. wesenbergii being rarely found toxic, while the majority of 484 M. aeruginosa and M. viridis is reported as toxic (Harke et al., 2016, Otten et al., 485 2017). The MC concentration in the reservoir and the estuary was most likely due to Microcystis sp., due to its overwhelming dominance and the high percentage of potentially toxic species within that genus in Brittany (Pitois et al., 2014). P. agardhii 
488 is also known to produce MCs in relatively large quantities (Briand et al., 2009; Lance 489 et al., 2007) and the most toxic bloom reported in Italy's estuarine waters was indeed one of Planktothrix (De Pace et al., 2014).

492 Few studies report on the different variants of $\mathrm{MC}$ during blooms in the natural 493 environment although their identification is important as different variants display 494 different toxicities and health risks (Lehman et al., 2008; Otten et al., 2017). 495 Toxicological studies reported on similar LD $_{50}$ values for MC-LR, MC-LA, MC-YR and 496 MC-YM while the value for MC-RR was 10 times higher (Sivonen and Jones, 1999), while Gupta et al., 2003 reported that MC-LR was twice as toxic as MC-LA. The dominant MCs variants (MC-LR and MC-RR in 2017 and (MC-LR, MC-RR and MCYR in 2016) were transferred without specific selection along the salinity gradient. The difference between the two years of the dominant variants may be attributed to different dominant Microcystis species as it is known that each species and strain produced, in culture conditions or in situ, different variants in different proportions and cell quantities (Rios et al., 2014; Briand et al., 2016; Otten et al., 2017). The demonstrated concentrations of the three dominant variants of $\mathrm{MC}$ reported in this study might therefore induce potential impacts on cyanobacterial consumers. Our preliminary data (unpublished) show MC accumulation by filter feeding organisms supporting this hypothesis. While we quantified 9 variants of $M C$ it is still possible that other variants were present in the samples.

In this study, a lysis of the cyanobacterial cells at high salinity was most likely as the ratio of extracellular $\mathrm{MC}$ to the total $\mathrm{MC}$ concentration increased downstream and in particular accounted for $100 \%$ of the total MC concentrations at the two most

513 downstream sites. In accordance with literature results the dominant form of $\mathrm{MC}$ in

514 the freshwater section was intracellular indicating its constitutive nature (Orr and 515 Jones, 1998; Briand et al., 2012), while the dominant form became extracellular as 516 cells lysis increased at elevated salinity (Tonk et al., 2007).

\section{Conclusion}

519 This study reports on the transfer of both cyanobacteria and cyanotoxins from a 520 freshwater reservoir to the marine outlet in France. Moreover, the transfer through 521 the estuary occurred frequently over the 2 year study period. The higher the 
522 concentrations upstream, the more intense the transfer. The very high correlation

523 between the biomass of potentially toxic species and total MC concentrations

524 suggests that the majority of the cyanobacterial present in the estuary were toxic.

525 Microcystis which dominated the blooms in the freshwater reservoir was the most

526 likely genus responsible for the measured MC concentrations in the estuary, followed

527 by $P$. agardhii both being relatively resistant to the salinity gradient. The extracellular

528 contribution to the total MCs increased from upstream to downstream in accordance

529 with cells lysis at elevated salinity. Both intracellular and extracellular MC variants did

530 not show specific selection along the salinity gradient and the dominance of two

531 highly toxic variants (i.e. MC-LR and MC-YR) is worrisome, as it could impact

532 cyanobacterial consumers.

\section{Acknowledgments}

536 The authors thank Alexandra Lepoutre, Maxime Georges des Aulnois and the PME

537 Minyvel Environnement for help with field work and Marion Lengronne for nutrient 538 analyses. Biochemical analyses and microscopy were supported by the Experimental 539 Ecology (ECOLEX) and the Analytical (PLAY) platforms from the UMR Ecobio. This 540 project was financed by the ANSES (Agence Nationale de Sécurité Sanitaire de 541 I'Alimentation, de l'environnment et du travail) under the Bieautox project EST-2015542191.

558 Anon, 2005. Anonyme ISO 20179:2005(E). Water quality - Determination of

559 microcystins - Method using solid phase extraction (SPE) and high performance

AFSSA, 2006. Rapport sur l'évaluation des risques liés à la présence de cyanobactéries et de leurs toxines dans les eaux destinées à l'alimentation, à la baignade et autres activités récréatives. $300 \mathrm{p}$.

Albay, M., Matthiensen, A., Codd, G.A., 2005. Occurrence of toxic blue green algae in the Kucukcekmece Lagoon (Istanbul, Turkey). Environ. Toxicol. 20 : 227-284.

Aminot, A., Chaussepied, M., 1983. Manuel des analyses chimiques en milieu marin. [Chemical analyses in marine waters guide]. Centre National pour l'Exploration des Océans CNEXO Editeur, Brest, France; 395 p. 
560 liquid chromatography (HPLC) with ultraviolet (UV) detection. International Standard 561 ISO 20179, first edition 2005-10-01, 17p.

Black, K., Yilmaz, M., Phlips, E.J., 2011. Growth and toxin production by Microcystis aeruginosa PCC 7806 (Kutzing) Lemmerman at elevated salt concentrations. J.

Briand, E., Escoffier, N., Straub, C., Sabart, M., Quiblier, C., 2009. Spatiotemporal changes in the genetic diversity of a bloom-forming Microcystis aeruginosa (cyanobacteria) population. ISME J 3: 419-429.

Briand, E., Bormans, M., Quiblier, C., Salençon, M.J., Humbert, J.F., 2012. Evidence of the cost of the production of microcystins by Microcystis aeruginosa under differing light and nitrate environmental conditions. PLoS One 7 (1), e29981.

Briand, E., Bormans, M., Gugger, M., Dorrestein, P.C., Gerwick , W.H., 2016. Changes in secondary metabolic profiles of Microcystis aeruginosa strains in response to intraspecific interactions. Environmental microbiology 18 (2), 384-400.

Brient, L., Lengronne, M., Bormans, M., Fastner, J., 2009. First occurrence of cylindrospermopsin in freshwater in France. Environmental Toxicology 24 (4), 415420.

Chen, L., Maoa, F., Chira Kirumba, G., Jiang, C., Manefield, M., He, Y., 2015.

Changes in metabolites, antioxidant system and gene expression in Microcystis aeruginosa under sodium chloride stress. Ecotoxicology and Environmental Safety $122: 126-135$.

Churro, C., Azevedo, J., Vasconcelos, V., Silva, A., 2017. Detection of a Planktothrix agardhii Bloom in Portuguese Marine Coastal Waters. Toxins 9, 391 ; doi:10.3390/toxins9120391

De Pace, R., Vita, V., Bucci, M.S., Gallo, P., Bruno, M., 2014. Microcystin contamination in sea mussel farms from the Italian southern Adriatic coast following cyanobacterial blooms in the artificial reservoir. J. Ecosyst. 2014,1-11.

doi.org/10.1155/2014/374027.

Dörr, F.A., Pinto, E., Soares, R.M., Azevedo, S.M.F.O., 2010. Microcystins in South American aquatic ecosystems: occurrence, toxicity and toxicological assays. Toxicon $56,1247-1256$.

Fraisse, S., Bormans, M., Lagadeuc, Y., 2013. Morphofunctional traits reflect differences in phytoplankton community between rivers of contrasted flow regime. Aquatic Ecology 47: 315-327. doi:10.1007/s10452-013-9446-z

Funari, E., Manganelli, M., Buratti, F.M., Testai, E., 2017. Cyanobacteria blooms in water: Italian guidelines to assess and manage the risk associated to bathing and recreational activities. Science of the total environment 598: 867-880. 
607 Gibble, C.M., Kudela, R.M., 2014. Detection of persistent microcystin toxins at the 608 land-sea interface in Monterey Bay, California. Harmful Algae 39, 146-153.

609 Gibble, C.M., Peacock, M.B., Kudela, R.M., 2016. Evidence of freshwater algal toxins in marine shellfish: Implications for human and aquatic health. Harmful Algae, 59:5966.

612 Gupta, N., Pant, S.C., Vijayaraghavan, R., Rao, P.V.L., 2003 Comparative toxicity evaluation of cyanobacterial cyclic peptide toxin Microcystin variants ( $L R, R R, Y R$ ) in mice Toxicology 188(2-3):285-96

615 Harke, M.J., Steffen, M.M., Gobler, C.J., Otten, T.G., Wilhelm, S.W., Wood, S.A., 616 Paerl, H. W., 2016. A review of the global ecology, genomics, and biogeography of the toxic cyanobacterium Microcystis spp. Harmful Algae 54, 4-20.

Henriksen A, Selmer-Olsen AR. 1970. Automatic methods for determining nitrate and nitrite in water and soil extracts. Analyst. 95:514-518.

Ibelings, B.W., Backer, L.C., Kardinaal, W.E.A., et Chorus, I., 2014. Current approaches to cyanotoxin risk assessment and risk management around the globe: Harmful Algae, 40, 63-74.

Kaebernick, M. and Neilan, B.A., 2001. Ecological and molecular investigations of cyanotoxin production. FEMS Microbiol Ecol. 35(1):1-9

Karjalainen, M., Engstrom-Ost, J., Korpinen, S., Peltonen, H., Paakkonen, J.P., Cyanobacteria in the Northern Baltic Sea. Ambio, $36: 2-3$.

Kruk, C., Segura, A.M., Nogueira, L., Alcántara, I., Calliaria, D., Martínez de la Escalerad, G., Carballoa, C., Cabreraa, C., Sarthoua, F., Scavone, P., Piccini, C., 2017. A multilevel trait-based approach to the ecological performance of Microcystis aeruginosa complex from headwaters to the ocean. Harmful Algae $70: 23-36$.

Lance, L., Paty, C., Bormans, M., Brient, L., Gérard, C., 2007. Interactions between cyanobacteria and gastropods: II. Impact of toxic Planktothrix agardhii on the lifehistory traits of Lymnaea stagnalis. Aquatic Toxicology 81 (4), 389-396

Lance, E., Brient, L., Carpentier, A., Acou, A., Marion, L., Bormans, M., Gérard, C., 2010. Impact of toxic cyanobacteria on gastropods and microcystin accumulation in a eutrophic lake (Grand-Lieu, France) with special reference to Physa (= Physella) acuta. Science of the Total Environment 408, 3560-3568.

Lehman, P.W., Boyer, G., Hall, C., Waller, S., Gehrts, K., 2005. Distribution and toxicity of a new colonial Microcystis aeruginosa bloom in the San Francisco Bay Estuary, California. Hydrobiologia 541, 87-99.

Lehman, P.W., Boyer, G., Satchwell, M., Waller, S., 2008. The influence of environmental conditions on the variation of Microcystis cell density and microcystin concentration in San Francisco Estuary. Hydrobiologia 600, 187- 204. 
Le Moal, M., Gascuel-Odoux, C., Menesquen, A., Souchon, Y., Etrillard, C., Levain, 654 A., Moatar, F., Pannard, A., Souchu, P., Lefebvre, A., Pinay, G., 2019. Eutrophication: A new wine in an old bottle? Science of the total environment. DOI:10.1016/j.scitotenv.2018.09.139

Lewitus, A.J., Brock, L.M., Burke, M.K., DeMattio, K.A., Wilde, S.B., 2008. Lagoonal stormwater detention ponds as promoters of harmful algal blooms and eutrophication along the South Carolina Coast. Harmful Algae 8, 60-65.

Lopes, V.R. and Vasconscelos, V., 2011. Planktonic and benthic cyanobacteria of European brackish waters: A perspective on estuaries and brackish seas European Journal of Phycology 46(3), 292-304. DOI: 10.1080/09670262.2011.602429

Martín-Luna, B., Sevilla, E., Bes, M.T., Fillat, M.F., Peleato, M.L., 2015. Variation in the synthesis of microcystin in response to osmotic stress in Microcystis aeruginosa PCC7806. Limnetica 34 (1), 205-214.

Martínez de la Escalera, G., Kruk, C., Segurad, A.M., Nogueira, L., Alcántara, I., Piccini, C., 2017. Dynamics of toxic genotypes of Microcystis aeruginosa complex (MAC) through a wide freshwater to marine environmental gradient. Harmful Algae $62: 73-83$

Merel, S., Walker, D., Chicana, R., Snyder, S., Baurés, E., Thomas, O., 2013. State of knowledge and concerns on cyanobacterial blooms and cyanotoxins. Environ. Int. $59,303-327$.

Meriluoto, J., Blaha, L., Bojadzija, G., Bormans, M., Brient, L., Codd, G.A., Drobac, D., Faassen, E.J., Fastner, J., Hiskia, A., Ibelings, B.W., Kaloudis, T., Kokocinski, M., Kurmayer, R., Pantelić, D., Quesada, A., Salmaso, N., Tokodi, N., Triantis, T.M., Visser, P.M., Svirčev, Z., 2017. Toxic cyanobacteria and cyanotoxins in European waters - recent progress achieved through the CYANOCOST Action and challenges for further research. Advances in Oceanography and Limnology, 8(1) DOI: 10.4081/aiol.2017.6429

Metcalf, J.S., Codd, G.A., 2012. Cyanotoxins: In B. A. Whitton (ed.) The Ecology of Cyanobacteria II. Their Diversity in Space and Time, Second Edition, Springer, Dordrecht, 651-675pp.

Miller, M.A., Kudela, R.M., Mekebri, A., Crane, D., Oates, S.C., Tinker, M.T., Staedler, W. A., Miller, M., Toy-Choutka, W.A., Dominik, S., Hardin, C., Langlois, D., Murray, G., Ward, M.K., Jessup, D.A., 2010. Evidence for a novel marine harmful algal bloom: cyanotoxins (microcystin) transfer from land to sea otters. PLoS One 5 (9), 1-11.

Murphy J, Riley JP. 1962. A modified single solution method for the determination of phosphate in natural waters. Anal Chim Acta. 27:31-36. 
Ndlela, L.L., Oberholster, P.J., Van Wyk, J.H., Cheng, P.H., 2016. An overview of cyanobacterial bloom occurences and research in Africa over the last decade. Harmful Algae 60, 11-26.

Omidi, A., Esterhuizen-Londt, M., Pflugmacher, S., 2017. Still challenging: the ecological function of the cyanobacterial toxin microcystin - What we know so far. Toxin Reviews, 37, Issue 2.

O'Neil, J.M., Davis, T.W., Burford, M.A., Gobler, C.J., 2012. The rise of harmful Harmful Algae 14 : 313-334

Orr, P.T., Jones, G.J., 1998. Relationship between microcystin production and cell division rates in nitrogen-limited Microcystis aeruginosa cultures. Limnol Oceanogr 43: 1604-1614.

Orr, P.T., Jones, G.J., Douglas, G.B., 2004. Response of cultured Microcystis aeruginosa from the Swan River, Australia, to elevated salt concentration and consequences for bloom and toxin management in estuaries. Mar. Freshw. Res. 55 (3), 277- 283.

Ortiz et al., 2017: A high throughput targeted and non-targeted method for the analysis of microcystins and anatoxin-A using on-line solid phase extraction coupled to liquid chromatography-quadrupole time-of-flight high resolution mass spectrometry. Analytical and Bioanalytical Chemistry. 409 (21): 4959-4969.

Otten, T.G., Paerl, H.W., Dreher, T.W., Kimmerer, W.J., and Parker, A.E., 2017. The molecular ecology of Microcystis sp. blooms in the San Francisco Estuary. Environmental Microbiology, 19(9), 3619-3637.

Paerl, H., 1988. Nuisance phytoplankton blooms in coastal, estuarine and inland waters. Limn. Ocean. 33: 823-847.

Paerl, H., 2018. Mitigating Toxic Planktonic Cyanobacterial Blooms in Aquatic Ecosystems Facing Increasing Anthropogenic and Climatic Pressures. Toxins, 10, 76; doi:10.3390/toxins10020076

Paerl, H.W., Otten, T.G., Kudela, R., 2018. Mitigating the Expansion of Harmful Algal Blooms Across the Freshwater-to-Marine Continuum. Environ. Sci. Technol. 52 : 5519-5529

Paldavičiene A., Mazur-Marzec, H., Razinokovas, A., 2009. Toxic cyanobacteria blooms in the Lithuanian part of the Curonian Lagoon. Oceanologia 51 (2), 203-216.

Peacock, M.B., Gibble, C.M., Senn, D.B., Cloern, J.E., Kudela, R.M., 2018. Blurred lines: Multiple freshwater and marine algal toxins at the land-sea interface of San Francisco Bay, California. Harmful Algae 73, 138-147.

Pitois, F., Thoraval, I., Baurès, E., Thomas, O., 2014. Geographical Patterns in Cyanobacteria Distribution: Climate Influence at Regional Scale. Toxins, 6, 509-522. 
Pitois, F., Fastner, J., Pagotto, C., Dechesne, M., 2018. Multi-Toxin Occurrences in

Preece, E.P., Hardy, F.J., Moore, B.C., Bryan, M., 2017. A review of microcystin detections in Estuarine and Marine waters: Environmental implications and human health risk. Harmful Algae 61, 31-45.

Puddick, J., Prinsep, M.R., Wood, S.A., Kaufononga, S.A.F., Cary, S.C., Hamilton, D.P., 2014. High Levels of Structural Diversity Observed in Microcystins from Microcystis CAWBG11 and Characterization of Six New Microcystin Congeners. Mar. Drugs, 12, 5372-5395; doi:10.3390/md12115372

R Development Core Team. 2011. R: a language and environment for statistical computing. Vienna (Austria): R Foundation for Statistical Computing, Vienna, Austria http://www.r-project.org/

Rigosi, A., Carey, C.C., lbelings, B.W., Brookes, J.D., 2014. The interaction between climate warming and eutrophication to promote cyanobacteria is dependent on trophic state and varies among taxa Limnol. Oceanogr., 59(1), 99-114.

Rinehart, K.L., Harada, K., Namikoshi, M., Chen, C., Harvis, C.A., Munro, M.H .G., Blunt, J.W., Mulligan, P.E., Beasley, V.R., Dahlem, A.M., Carmichael, W.W.,1988. Nodularin, microcystin, and the configuration of Adda. J. Am. Chem. Soc. 11025 : 8557-8558

Ríos, V., Moreno, I., Prieto, A. I., Soria-Díaz, M. E, Frías J.E. and Cameán, A.M., 2014. Comparison of Microcystis aeruginosa (PCC7820 and PCC7806) growth and intracellular microcystins content determined by liquid chromatography-mass spectrometry, enzyme-linked immunosorbent assay, anti-Adda and phosphatase bioassay. Journal of Water and Health.12.1, 69-80.

Robson, B.J., Hamilton, D.P., 2003. Summer flow event induces a cyanobacterial bloom in a seasonal western Australia estuary. Mar. Freshw. Res. 54, 139-151.

Sivonen, K., Jones, G., 1999. Cyanobacterial Toxins. In: Chorus, I. and Bartram, J., Eds., Toxic Cyanobacteria in Water: A Guide to Their Public Health Consequences, Monitoring, and Management, E \& FN Spon, London, 41-111.

Sivonen, K., Kononen, K., Carmichael, W., Dahlem, A.M., Rinehart, K.L., Kiviranta, J., Niemela, S.I., 1989. Occurrence of the hepatotoxic cyanobacterium Nodularia spumigena in the Baltic Sea and structure of toxin. Applied and Environmental Microbiology 55(8):1990-5

Taş, S., Okus, E., Aslan-Yilmaz, A., 2006. The blooms of a cyanobacterium, Microcystis cf. aeruginosa in a severely polluted estuary, the Golden Horn, Turkey. Estuar. Coast. Shelf Sci. 68, 593-599.

Tatters , A.O., Howard , M.D .A., Nagoda , C., Busse, L., Gellene , A.G., Caron, D.A., 2017 Multiple stressors at the land-sea interface: cyanotoxins at the land-sea 
interface in the Southern California Bight. Toxins, 9, 95.

Tillett, D., Dittmann, E., Erhard, M., von Döhren, H., Börner, T., Neilan, B.A., 2000. Structural organization of microcystin biosynthesis in Microcystis aeruginosa PCC7806: an integrated peptide polyketide synthetase system. Chemistry \& Biology, 7:753-764

Tonk, L., Bosch, K., Visser, P.M., Huisman, J., 2007. Salt tolerance of the harmful cyanobacterium Microcystis aeruginosa. Aquat. Microb. Ecol. 46, 117-123.

Umehara, A., Tsutsumi, H., Takahashi, T., 2012. Blooming of Microcystis aeruginosa in the reservoir of the reclaimed land and discharge of microcystins to Isahaya Bay (Japan). Environ. Sci. Pollut. Res. 19, 3257-3267.

Vergalli, J., Bertrand, C., Borla, A., Franquet, E., Fayolle, S., 2016. Salt tolerance of Planktothrix agardhii (Gomont) Anagnostidis \& Komárek (cyanoprokaryota) between freshwater and brackish strains in batch cultures. Algological Studies $150: 3-20$.

Verspagen, J.M.H., Passarge, J., Jöhnk, K.D., Visser, P.M., Peperzak, L., Boers, P., Laanbroek, H.J., Huisman, J., 2006. Water management strategies against toxic Microcystis blooms in the Dutch delta. Ecol. Appl. 16, 313-327.

Vezie, C., Brient, L., Sivonen, K., Bertru, G., Lefeuvre, J.C., Salkinoja-Salonen, M., 1998. Variation of microcystin content of cyanobacterial blooms and isolated strains in Lake Grand-Lieu (France). Microb Ecol 35:126-35. 


\section{Figure}

Click here to download high resolution image

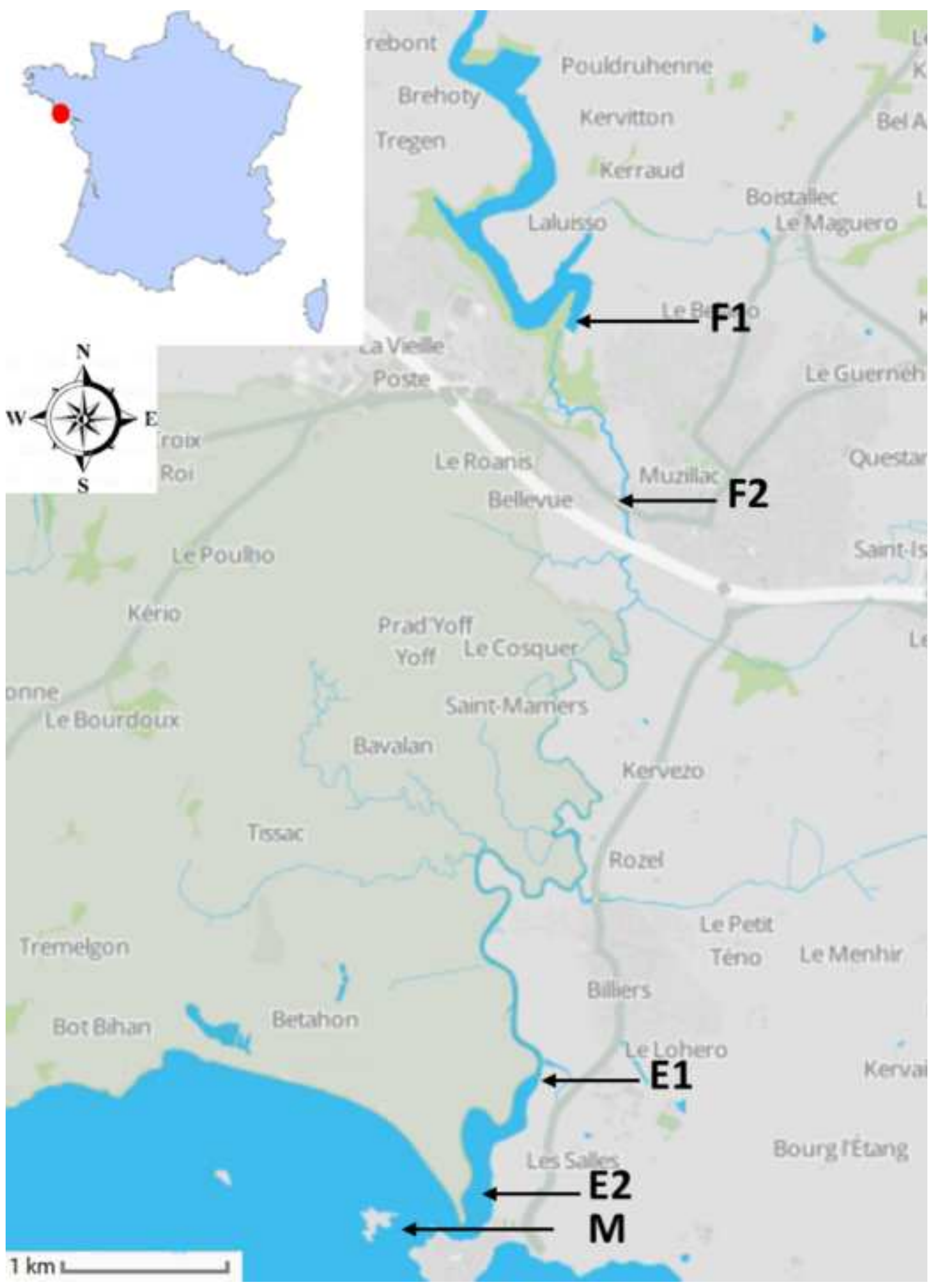


Click here to download high resolution image

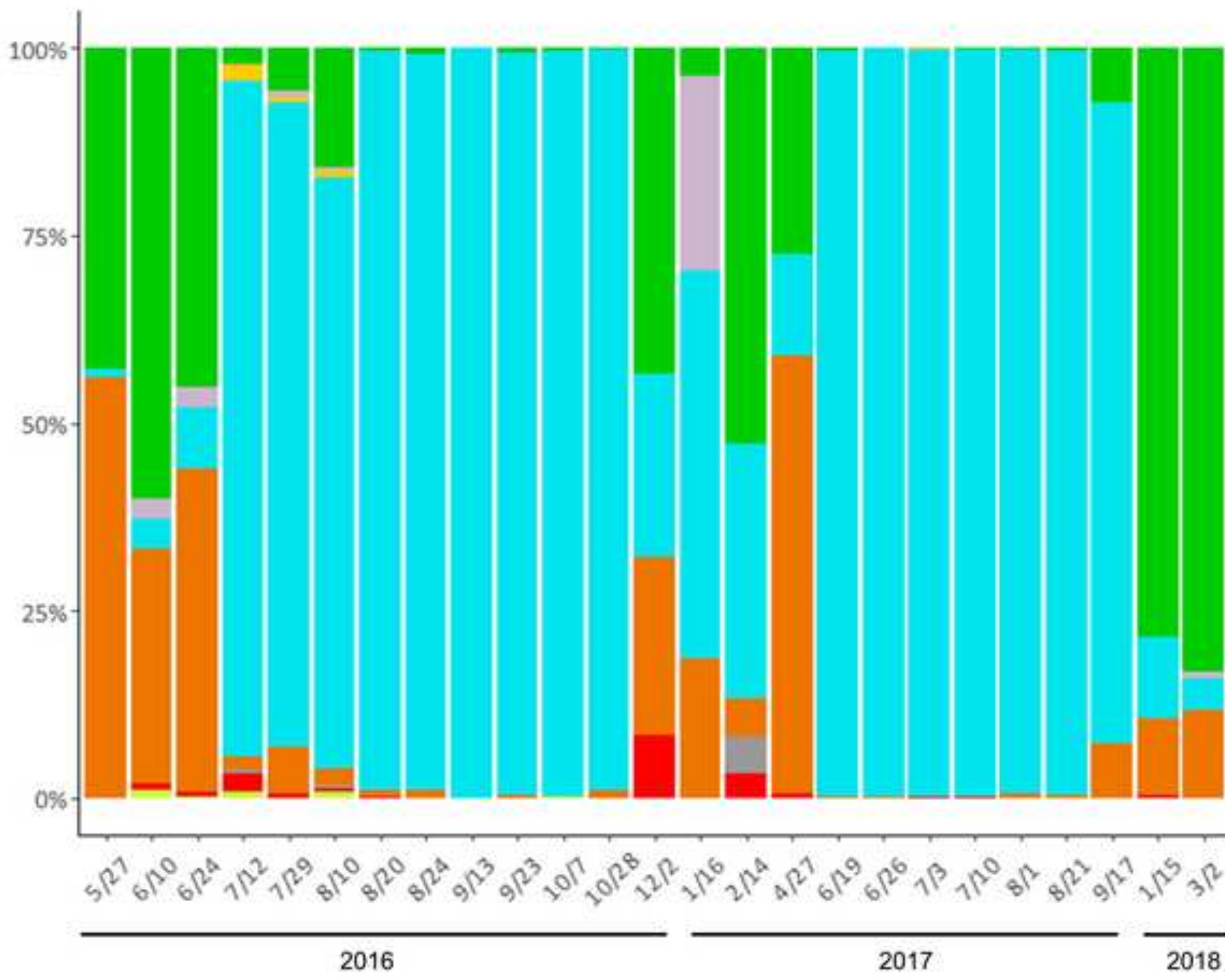

CYANOBACTERIA CHLOROPHYCEAE DIATOMOPHYCEAE EUGLENOPHYCEAE CRYPTOPHYCEAE ZYGOPHYCEAE DINOPHYCEAE CHRYSOPHYCEAE 


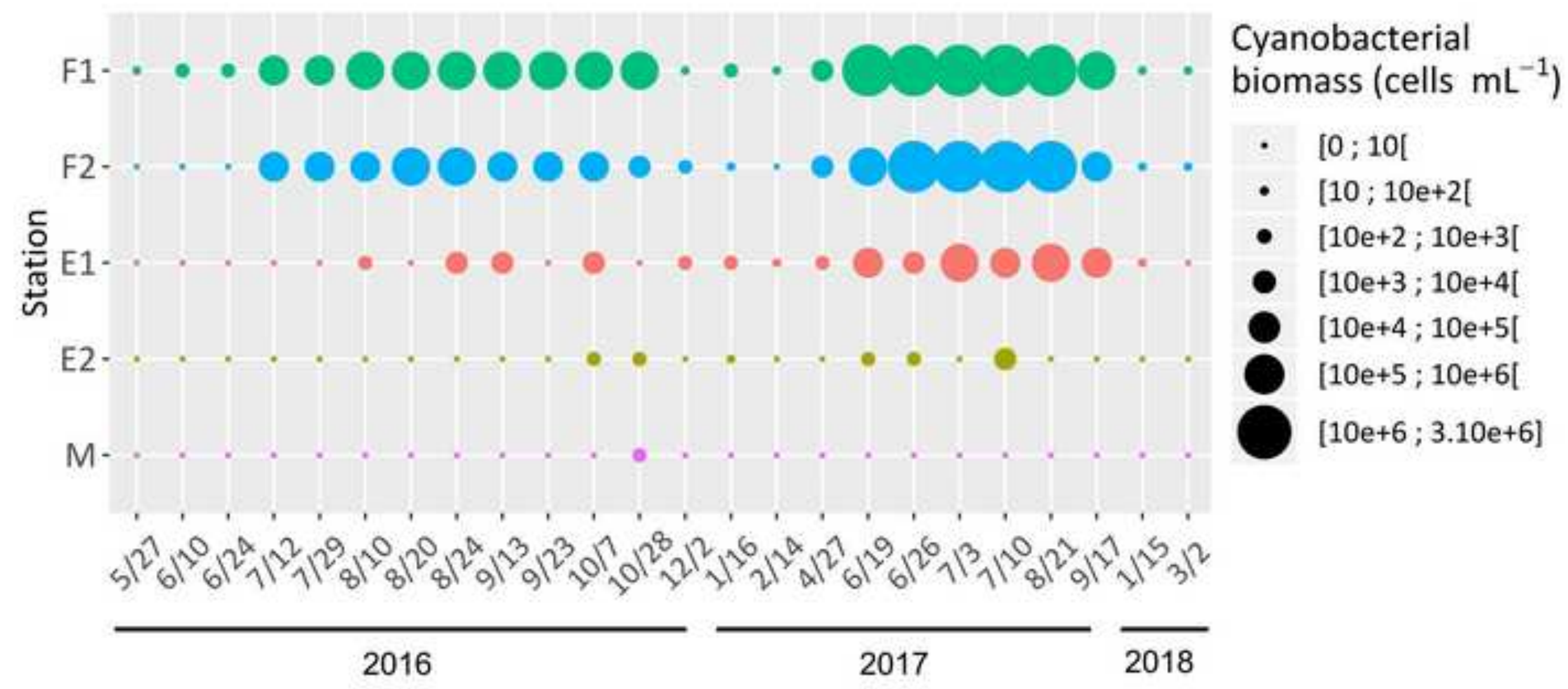

Cyanobacterial

- $10 ; 10[$

- $[10 ; 10 \mathrm{e}+2 \mathrm{l}$

- $[10 \mathrm{e}+2 ; 10 \mathrm{e}+3[$

- $[10 \mathrm{e}+3 ; 10 \mathrm{e}+4 \mathrm{I}$

- $[10 \mathrm{e}+4 ; 10 \mathrm{e}+5[$

- $[10 \mathrm{e}+5 ; 10 \mathrm{e}+6[$

$[10 \mathrm{e}+6 ; 3.10 \mathrm{e}+6]$ 

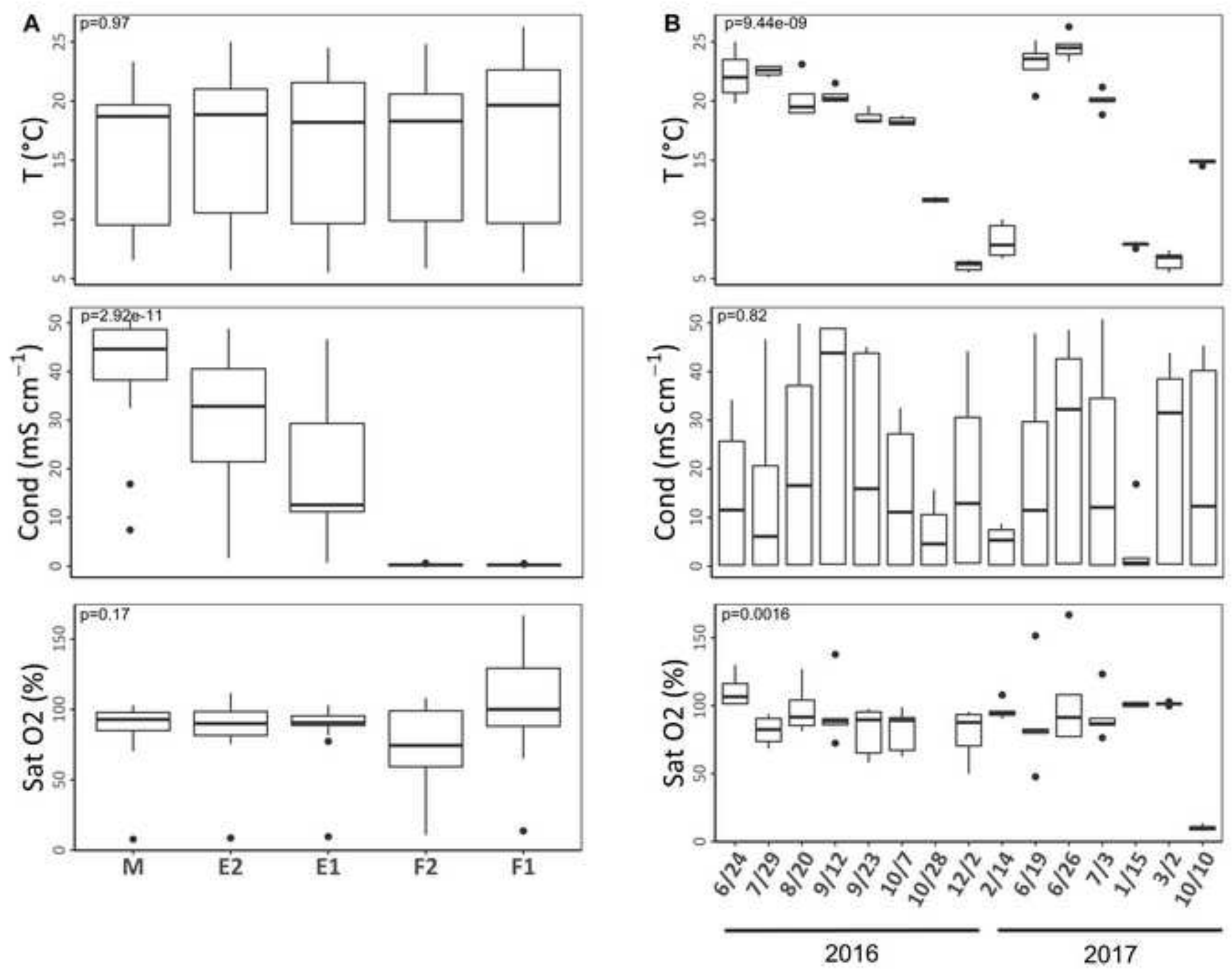
Click here to download high resolution image
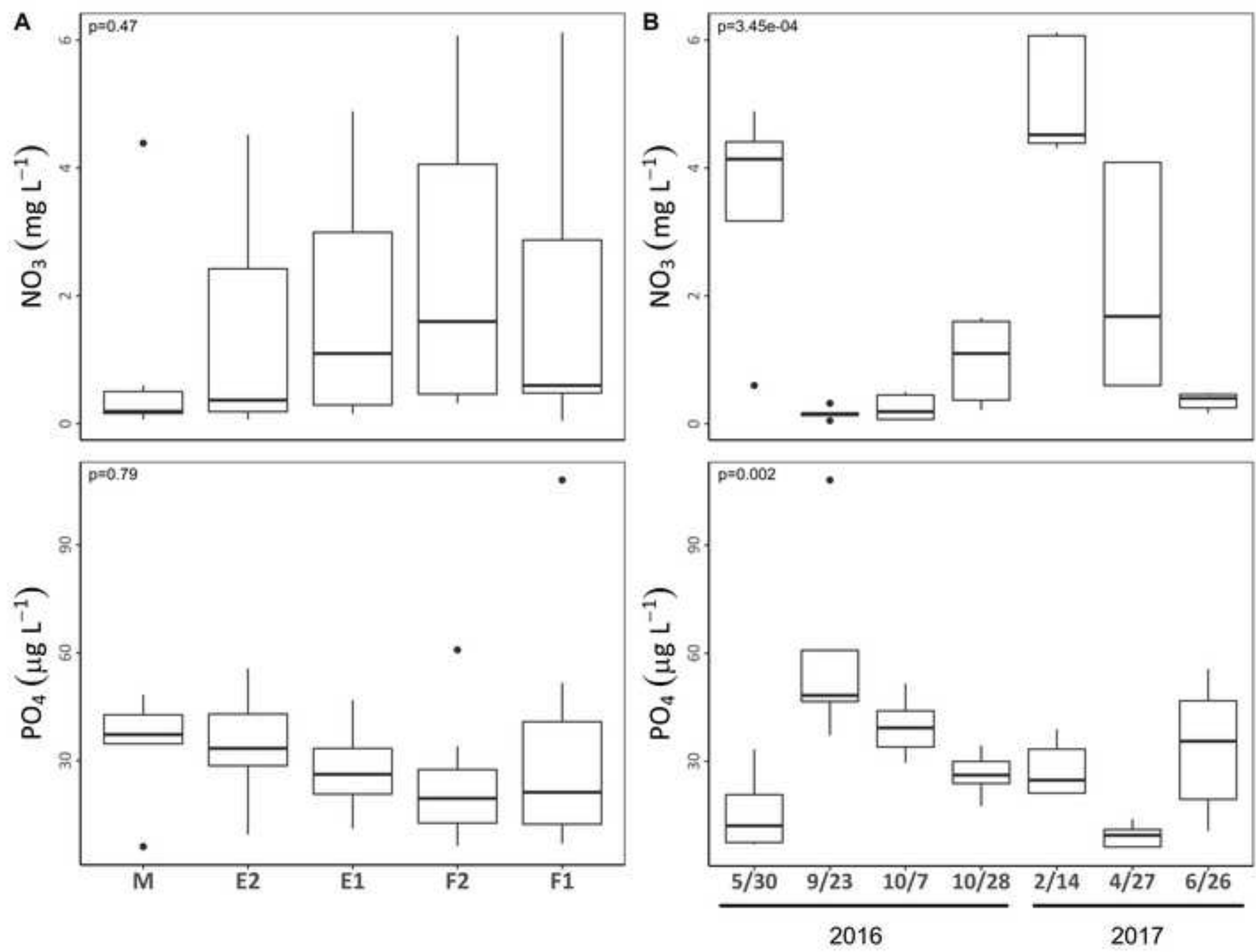
Click here to download high resolution image

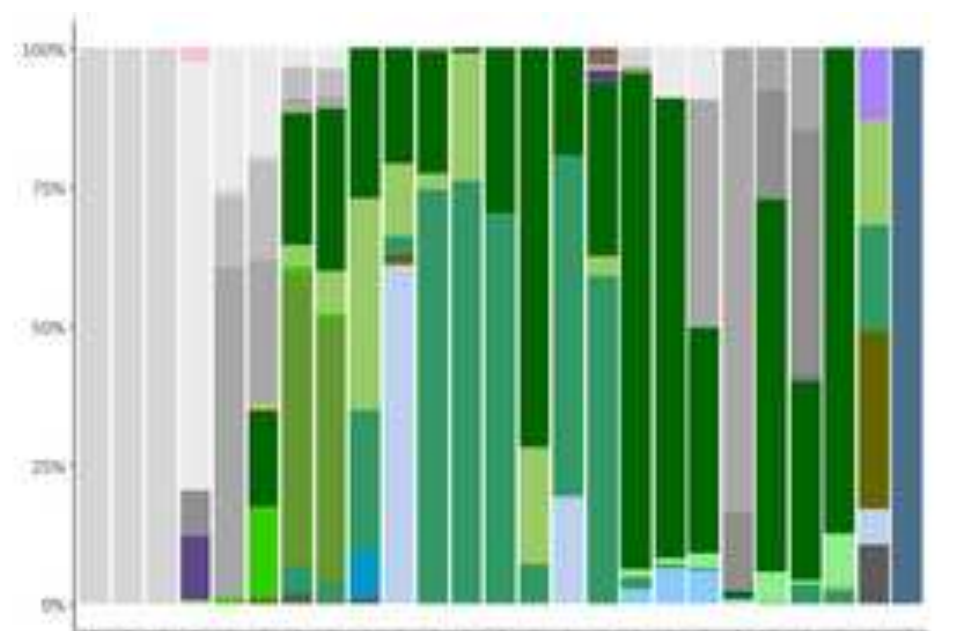

$\mathrm{A}=0$,

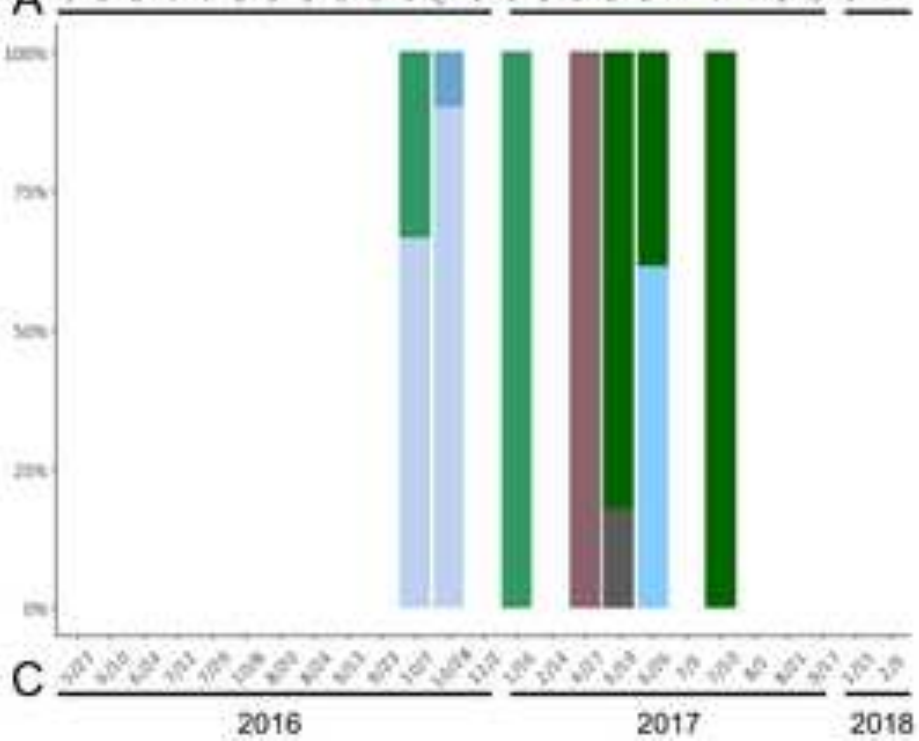

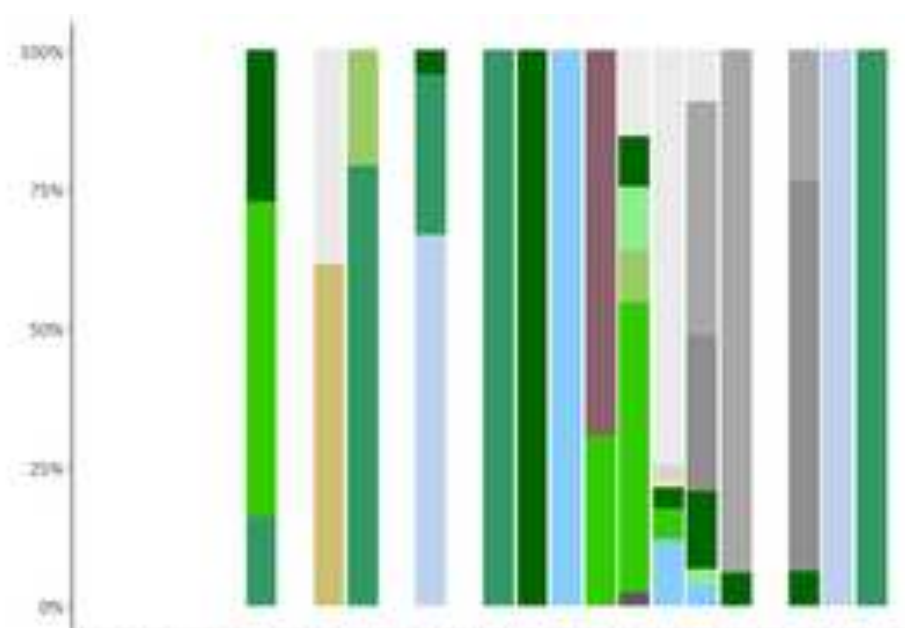

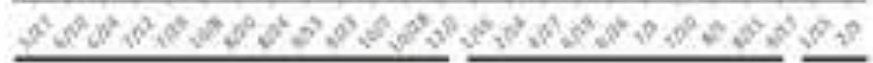

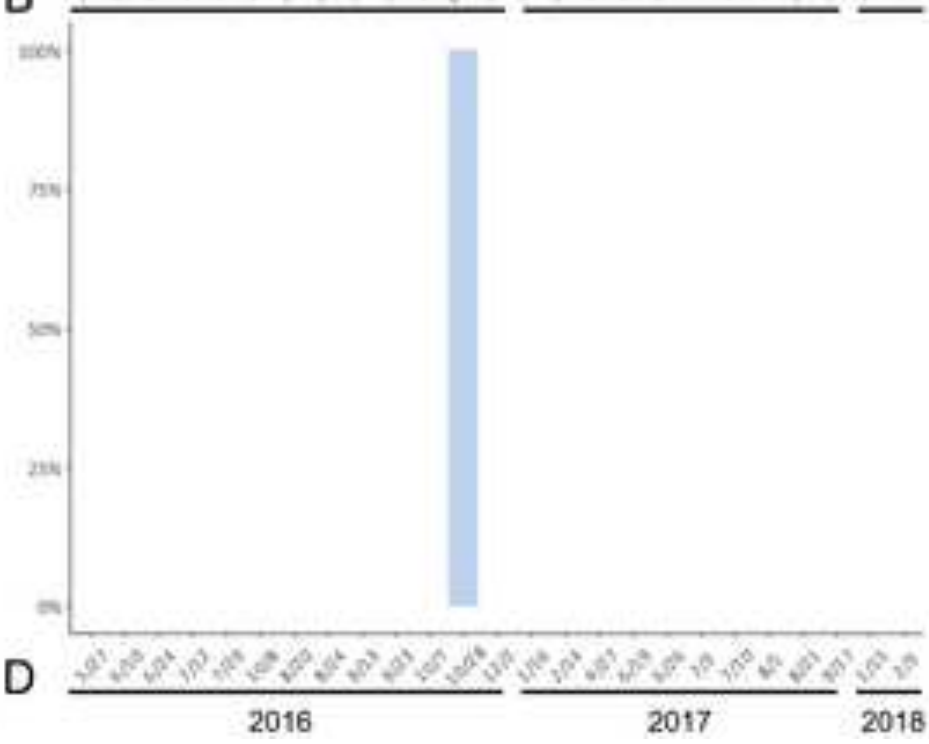

Aphanisomenon flos aquoe Aphanizomenon istotschenkol Aphanizomenon sp.

Dolichospermum plonctonica

Dolichospermum $s p$.

Dolichospermum spiraides

Umnothrix so.

Lyngbyas sp.

Oscillatoria spe

Phomidium sp.

Plonktothnix agardhil

Pseudonaboena limnetica

Pseudanaboena mucicola

Aphanocopso sp.

Chroococcus sp.

Coelosphoerium sp.

Cyanodictrion sp.

Cyanogranis sp.

Merismopedia tenaistime

Microcystis aetugineso

Mierocystis botrys

Mierocystis flos aquare

Microcystis nowacekif

Microcystis sp.

Mierocystis winlilis

Microsystis wesenbergif

Woranichinia spa. 
Click here to download high resolution image

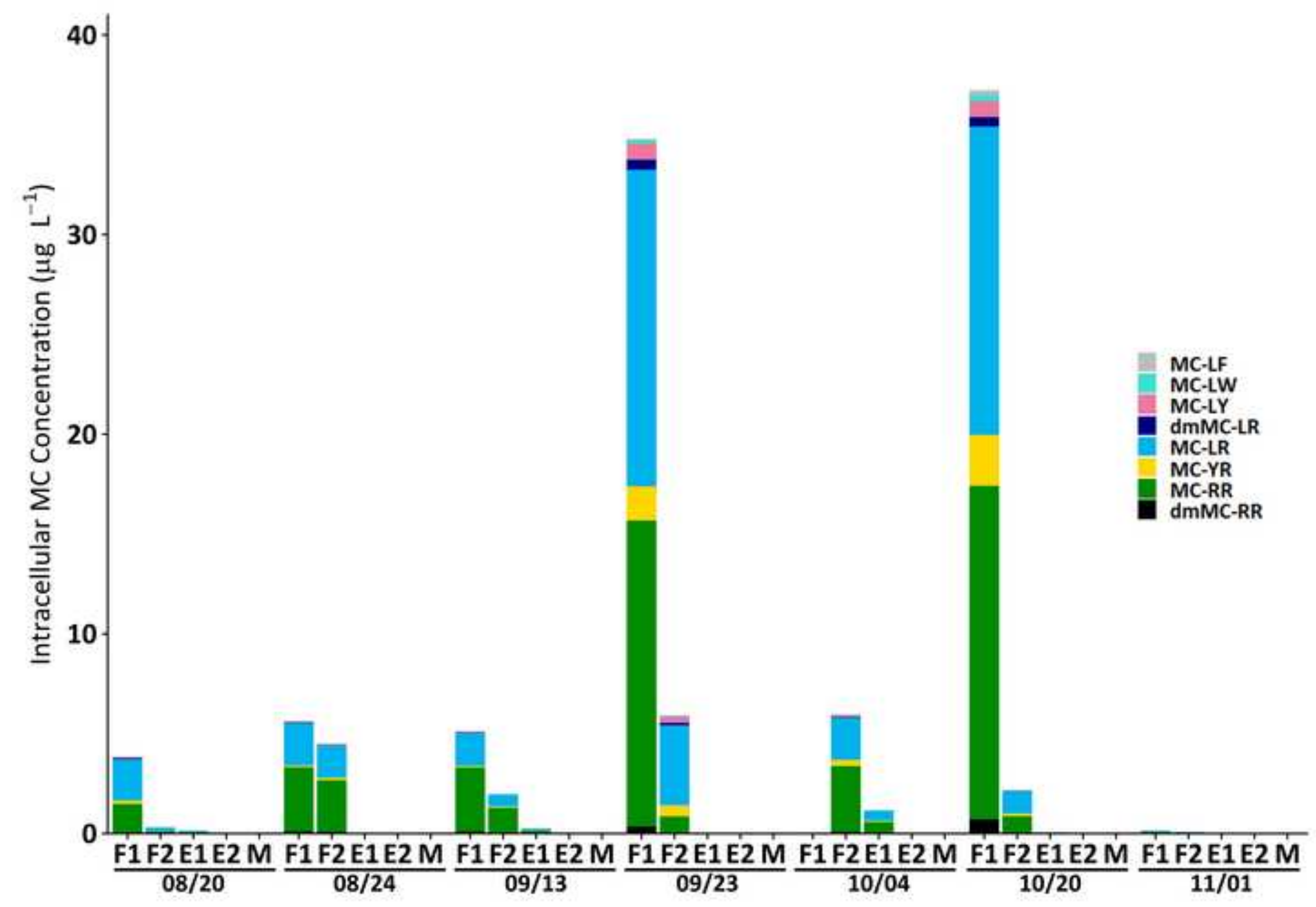


Click here to download high resolution image

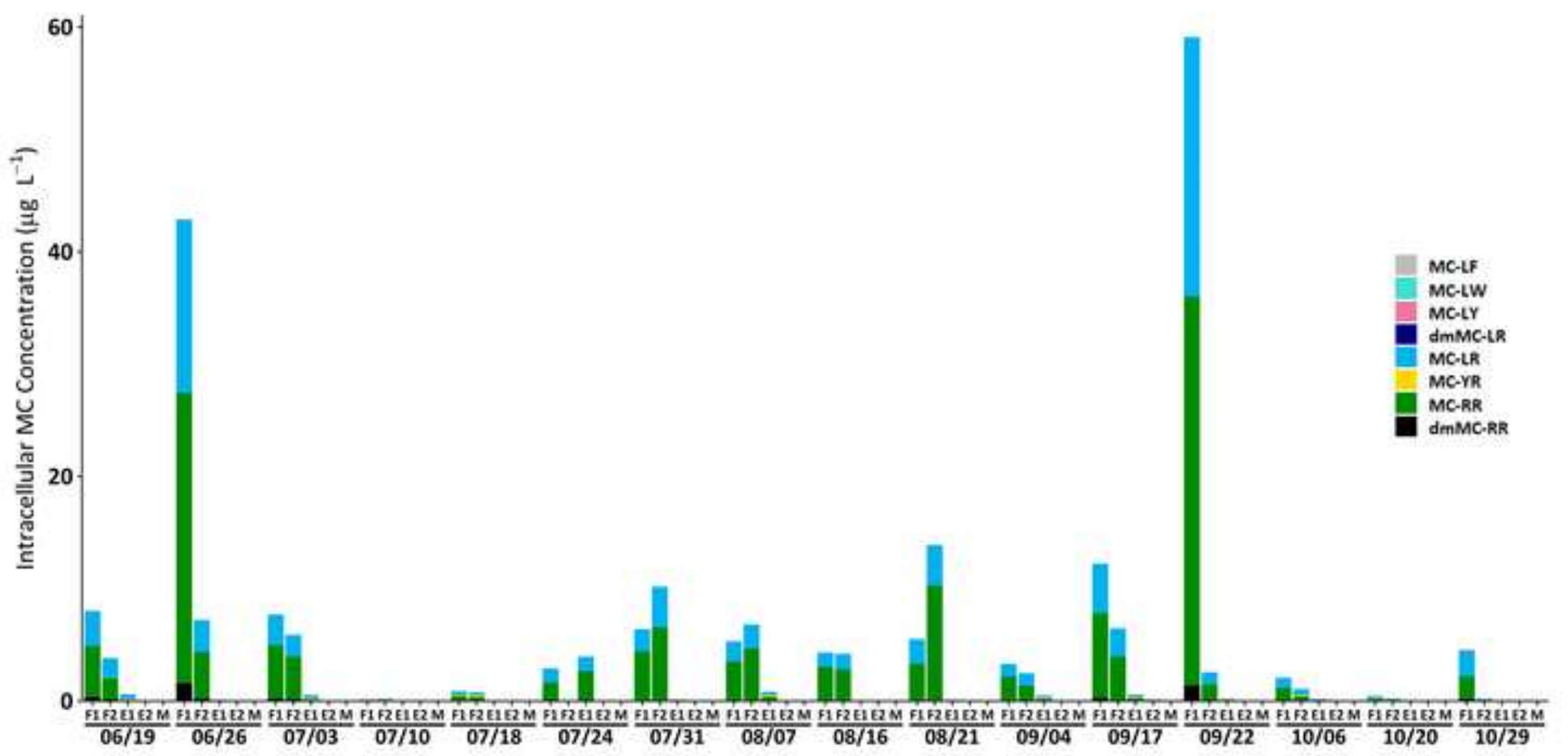




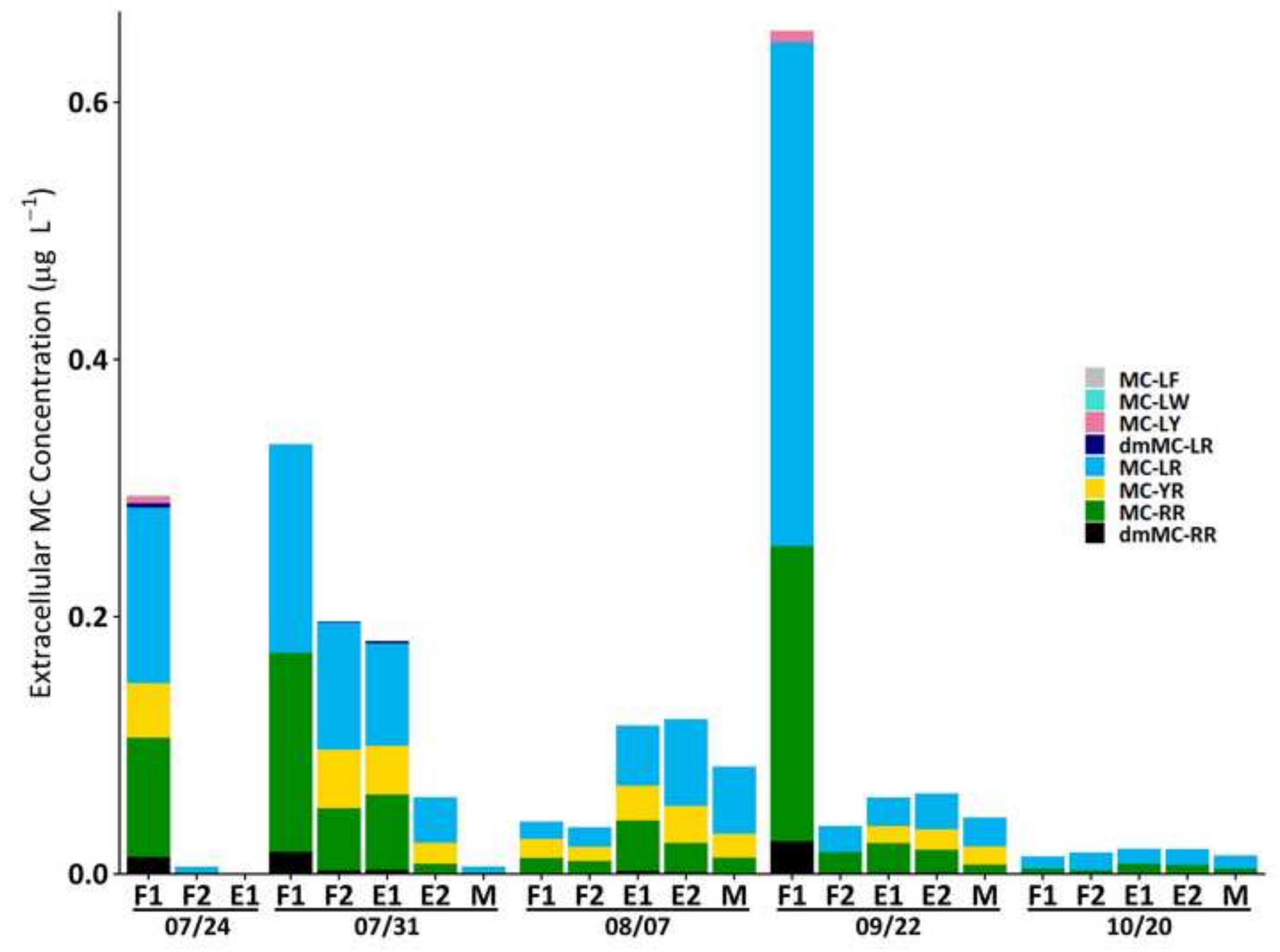




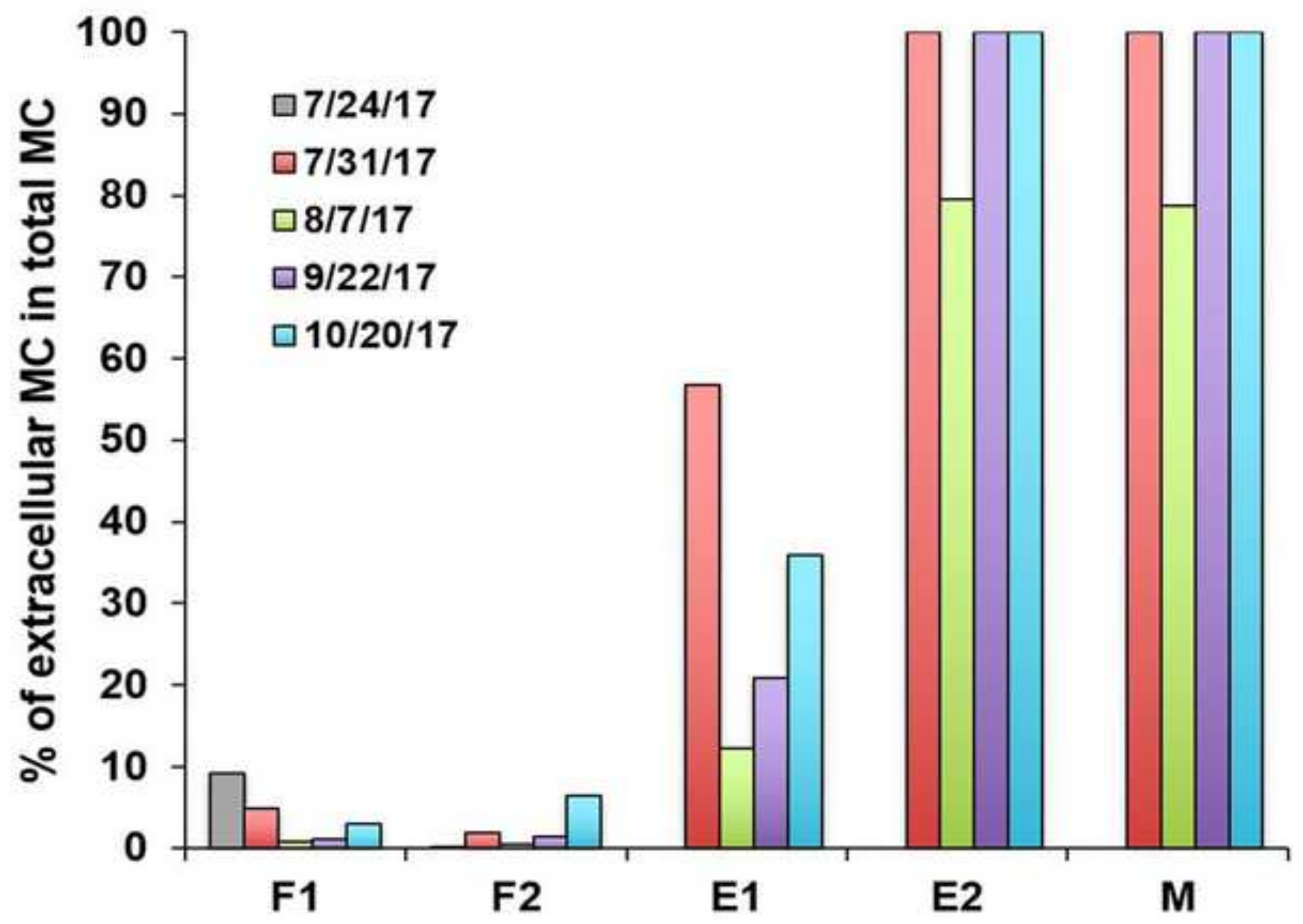




\begin{tabular}{|c|c|c|c|}
\hline Sites & \multicolumn{2}{|c|}{ FO \% intra MC (Jun - Nov) } & Max intra MC $\mathbf{\mu g} / \mathbf{L}$ \\
\hline F1 & 2016 & $\mathbf{2 0 1 7}$ & \\
\hline F2 & 100 & 100 & 60 \\
\hline E1 & 100 & 100 & 14 \\
\hline E2 & 67 & 87 & 1.15 \\
\hline M & 17 & 38 & 0.14 \\
\hline
\end{tabular}

Table 1: Frequency of occurrence (in \%) and maximum concentrations of intracellular $\mathrm{MC}$ at the 5 stations during the period June to November of both sampling years 
Table S1 : LC-MS/MS transitions for the 9 MC variants and NOD tested with standards

\begin{tabular}{|c|c|c|c|}
\hline Toxin & Precursor ion $(\mathrm{m} / \mathrm{z})$ & $\begin{array}{c}\text { Transition }(\mathrm{m} / \mathrm{z})- \\
\text { Quantification }\end{array}$ & $\begin{array}{c}\text { Transition }(\mathrm{m} / \mathrm{z})- \\
\text { identification }\end{array}$ \\
\hline MC-LR & 995.6 & 213.2 & 374.5 \\
\hline MC-LW & 1025.6 & 375.2 & 135.2 \\
\hline MC-LF & 986.6 & 375.2 & 135.2 \\
\hline MC-LY & 1002.6 & 375.2 & 135.2 \\
\hline dmMC-LR & 981.4 & 103.0 & 135.2 \\
\hline MC-RR & 520.1 & 135.2 & 213.2 \\
\hline dmMC-RR & 512.8 & 135.0 & 103.0 \\
\hline MC-LA & 910.7 & 375.2 & 135.2 \\
\hline MC-YR & 1045.6 & 213.2 & 375.2 \\
\hline NOD & 825.5 & 227.0 & 163.2 \\
\hline
\end{tabular}


Click here to download high resolution image

A
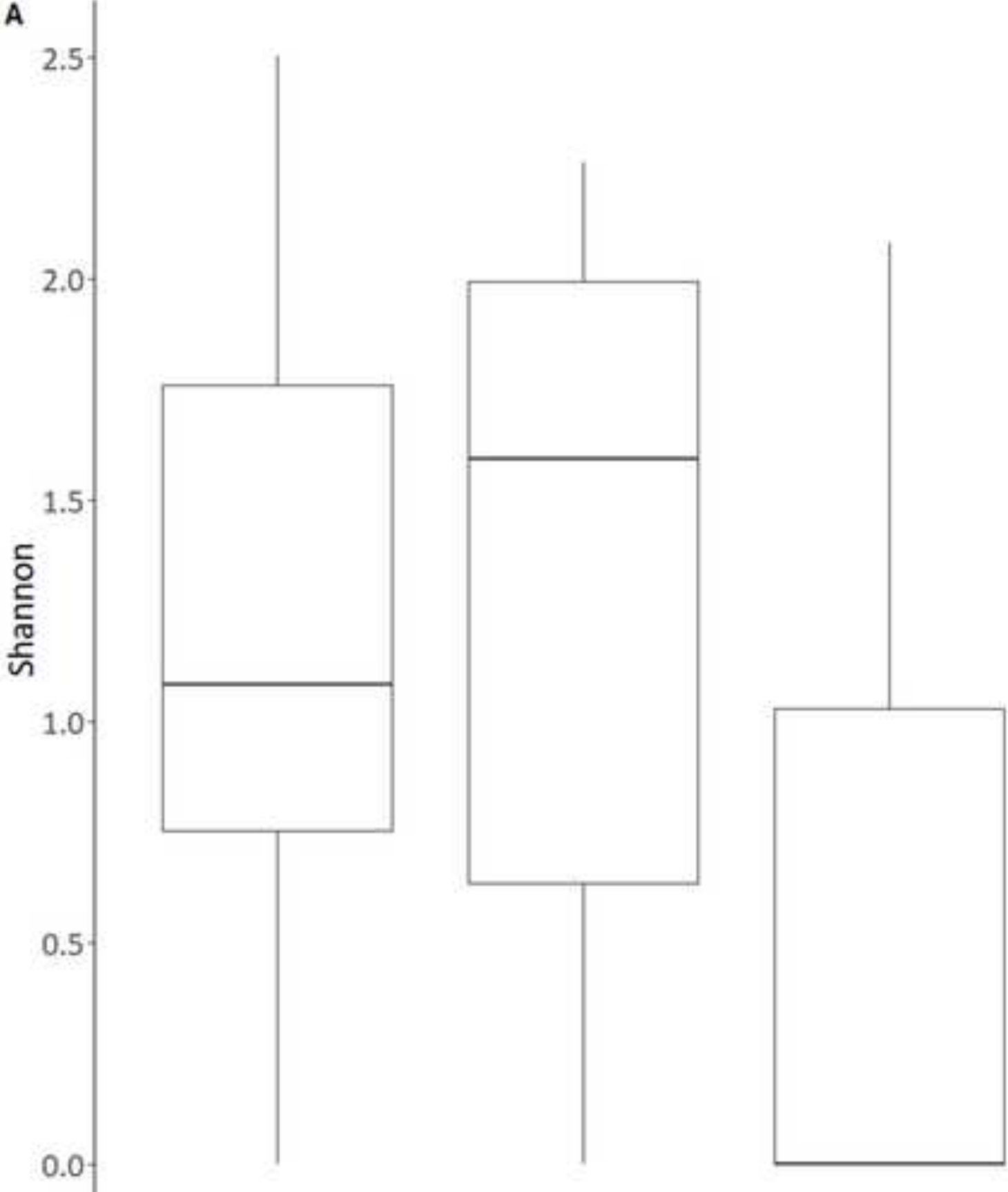

:

F1

F2

E1

E2 
Click here to download high resolution image

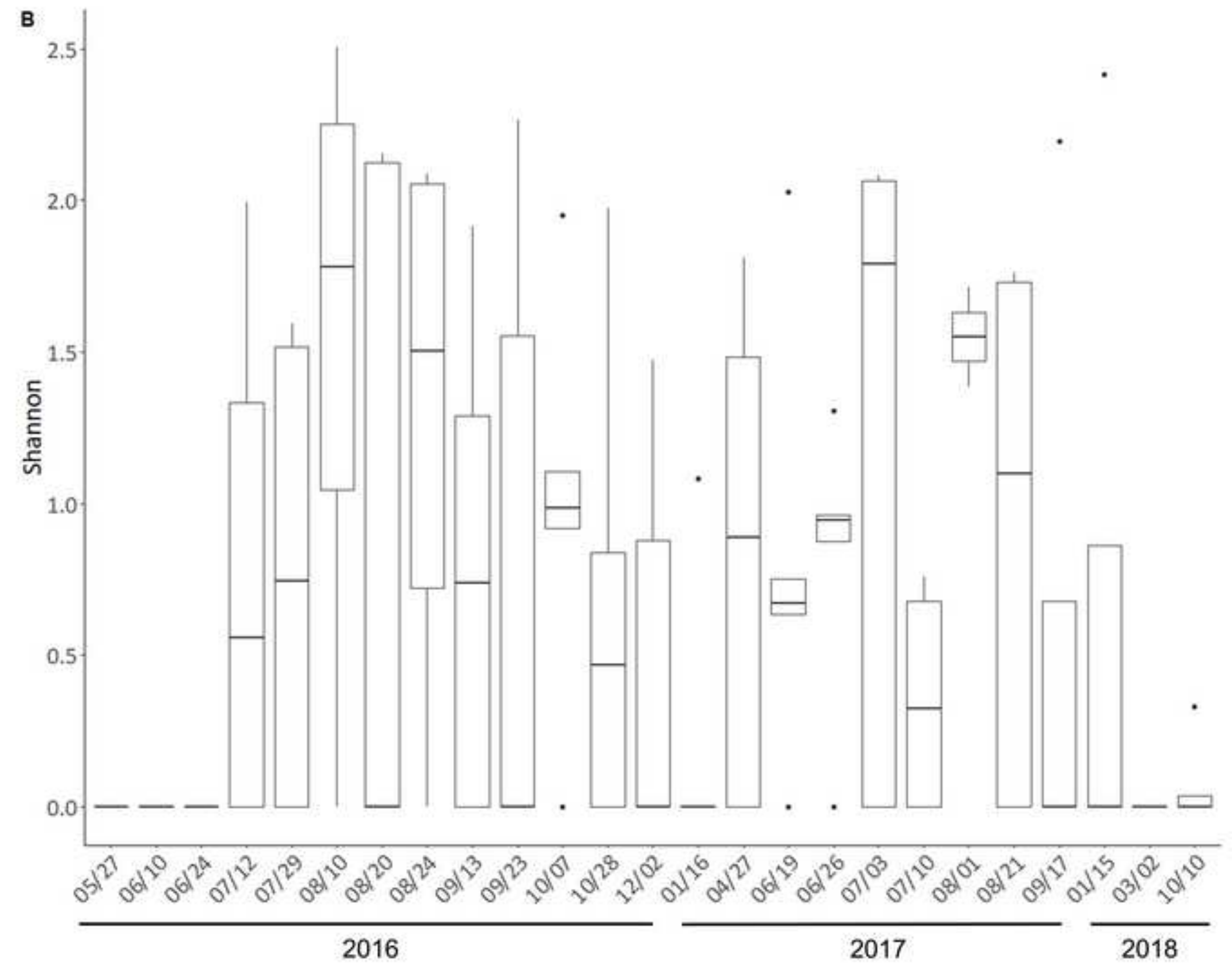




\section{(Axes F1 and F2: 63.91\%)}

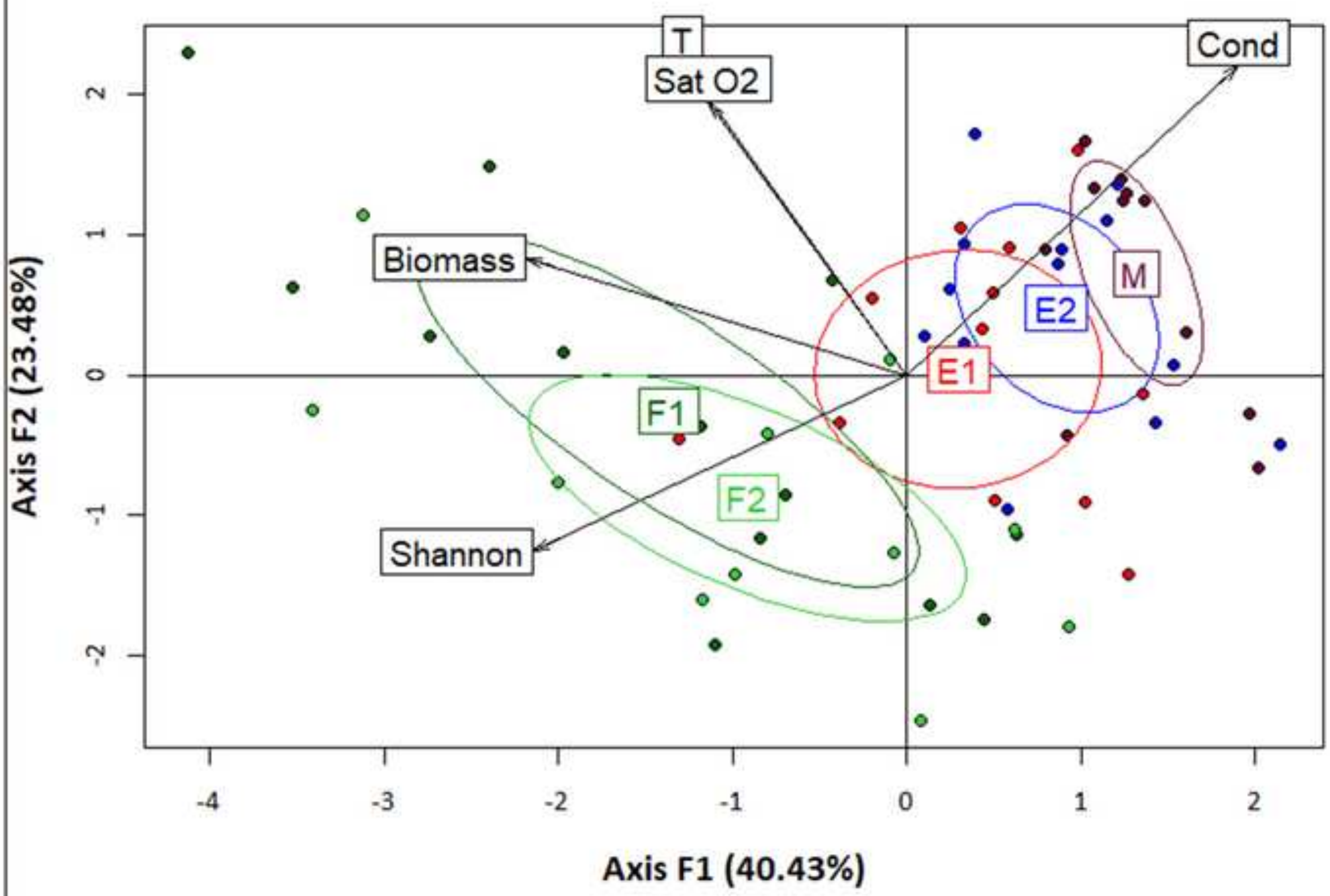

